FISCAL POLICY, INEQUALITY AND THE POOR IN THE DEVELOPING WORLD

Nora Lustig 


\section{The CEQ Working Paper Series}

The CEQ Institute at Tulane University works to reduce inequality and poverty through rigorous tax and benefit incidence analysis and active engagement with the policy community. The studies published in the CEQ Working Paper series are pre-publication versions of peer-reviewed or scholarly articles, book chapters, and reports produced by the Institute. The papers mainly include empirical studies based on the CEQ methodology and theoretical analysis of the impact of fiscal policy on poverty and inequality. The content of the papers published in this series is entirely the responsibility of the author or authors. Although all the results of empirical studies are reviewed according to the protocol of quality control established by the CEQ Institute, the papers are not subject to a formal arbitration process. The CEQ Working Paper series is possible thanks to the generous support of the Bill \& Melinda Gates Foundation. For more information, visit www.commitmentoequity.org.

The CEQ logo is a stylized graphical representation of a Lorenz curve for a fairly unequal distribution of income (the bottom part of the $\mathrm{C}$, below the diagonal) and a concentration

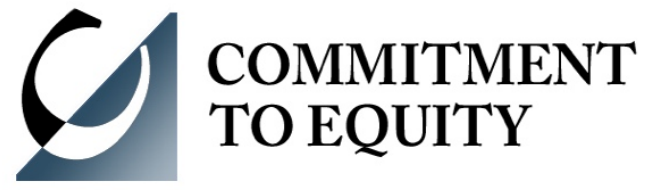
curve for a very progressive transfer (the top part of the $\mathrm{C}$ ). 


\title{
FISCAL POLICY, INEQUALITY AND THE POOR IN THE DEVELOPING WORLD*
}

\author{
Nora Lustig ${ }^{\dagger}$ \\ CEQ Working Paper 23 \\ OCTOBER 2016; REVISED JULY 2017
}

\begin{abstract}
Using comparable fiscal incidence analysis, this paper examines the impact of fiscal policy on inequality and poverty in twenty-five countries for around 2010. Success in fiscal redistribution is driven primarily by redistributive effort (share of social spending to GDP in each country) and the extent to which transfers/subsidies are targeted to the poor and direct taxes targeted to the rich. While fiscal policy always reduces inequality, this is not the case with poverty. Fiscal policy increases poverty in four countries using US $\$ 1.25 /$ day PPP poverty line, in 8 countries using US $\$ 2.50 /$ day line, and 15 countries using the US $\$ 4 /$ day line (over and above market income poverty). Net direct taxes are always equalizing and net indirect taxes are equalizing in seventeen out of the twentyfive countries. While spending on pre-school and primary school is pro-poor (i.e., the per capita transfer declines with income) in almost all countries, pro-poor secondary school spending is less prevalent, and tertiary education spending tends to be progressive only in relative terms (i.e., equalizing but not pro-poor). Health spending is always equalizing.
\end{abstract}

Keywords: H22, H5, D31, I3

JEL classification: fiscal incidence, social spending, inequality, poverty, developing countries

\footnotetext{
* This paper was prepared for UNU-WIDER and is as part of the research on fiscal redistribution by the Commitment to Equity Institute, Tulane University. Launched in 2008, the CEQ project is an initiative of the Center for Inter-American Policy and Research (CIPR) and the Department of Economics, Tulane University, the Center for Global Development and the Inter-American Dialogue. The CEQ project is housed in the Commitment to Equity Institute at Tulane. For more details, visit www.commitmentoequity.org. I am very grateful to Ruoxi Li, Israel Martinez, and Itzel Osorio as well as to Enrique de la Rosa for their excellent research assistantship. I am also grateful to Cristina Carrera, Israel Martinez, and Sandra Martinez for their excellent help in preparing the database used here. All errors and omissions remain my sole responsibility

† Nora Lustig is Samuel Z. Stone Professor of Latin American Economics and Director of the Commitment to Equity Institute (CEQI), Tulane University and nonresident fellow of the Center for Global Development and the Inter-American Dialogue. You can reach the author at nlustig@tulane.edu.
} 


\section{INTRODUCTION}

This paper analyzes the impact of fiscal policy on inequality and poverty in twenty-five low and middle income countries for around 2010. ${ }^{3}$ Using the World Bank classification, the group includes two lowincome countries: Ethiopia and Tanzania; nine lower middle-income countries: Armenia, Bolivia, El Salvador, Ghana, Guatemala, Honduras, Indonesia, Sri Lanka and Tunisia; eleven upper middle-income countries: Brazil, Colombia, Costa Rica, Dominican Republic, Ecuador, Georgia, Jordan, Mexico, Peru, Russia and South Africa; two high-income countries: Chile, and Uruguay; and, one unclassified (upper middle-income, most likely): Argentina. ${ }^{4}$ The data utilized here is based on the country studies available in the Commitment to Equity Institute's database on fiscal redistribution. ${ }^{5}$ The studies apply the same fiscal incidence methodology described in detail in Lustig and Higgins (2013) and Lustig (2017). With a long tradition in applied public finance, fiscal incidence analysis is designed to respond to the question of who benefits from government transfers and who ultimately bears the burden of taxes in the economy (Musgrave 1959; Pechman 1985; Martinez-Vazquez 2008). The fiscal policy instruments included here are: personal income and payroll taxes, direct transfers, consumption taxes, consumptions subsidies and transfers in-kind (in the form of education and healthcare services).

This article makes three main contributions. First, because the fiscal incidence analysis is comprehensive, one can estimate both the overall impact of fiscal policy as well as the marginal contribution of each instrument. Second, the analysis includes the effects of fiscal policy not only on inequality but also on poverty. Third, because the studies apply a common methodology, results are comparable across countries.

While fiscal policy unambiguously reduces income inequality, that is not always true for poverty. Using the lowest international poverty line (\$1.25 2005 PPP per day), the headcount ratio after cash transfers, net direct taxes and net indirect taxes is lower than the headcount ratio for market (pre-fiscal) income in twenty-one countries. In Ethiopia, Tanzania, Ghana and Guatemala, however, the headcount ratio is higher after taxes and transfers than before. In Tanzania and Ghana, the percentage increase in the headcount ratio is $17.8 \%$ and $13.3 \%$, respectively. When using the poverty lines of $\$ 2.50$ and $\$ 4.00(2005$ PPP per day), the number of countries where poverty increases rises to 8 and 15, respectively. In addition, to varying degrees, in all countries a portion of the poor are net payers into the fiscal system and are, thus, impoverished by the fiscal system (Higgins and Lustig, 2016).

\footnotetext{
3 Argentina (Rossignolo, 2018), Armenia (Younger and Khachatryan, 2016), Bolivia (Paz-Arauco et al., 2014a), Brazil (Higgins and Pereira, 2014), Chile (Martinez-Aguilar et al., 2018), Colombia (Lustig and Melendez, 2016), Costa Rica (Sauma and Trejos, 2014a), Dominican Republic (Aristy-Escuder et al., 2018), Ecuador (Llerena et al., 2015), El Salvador (Beneke et al., 2018), Ethiopia (Hill et al., 2017), Georgia (Cancho and Bondarenko, 2017), Ghana (Younger et al., 2017), Guatemala (Cabrera, Lustig, and Moran, 2015), Honduras (Icefi, 2017), Indonesia (Afkar et al., 2017), Jordan (Alam et al., 2017), Mexico (Scott, 2014), Peru (Jaramillo, 2014), Russia (Lopez-Calva et al., 2017), South Africa (Inchauste et al., 2017), Sri Lanka (Arunatilake et al., 2017), Tanzania (Younger et al., 2016a), Tunisia (Shimeles et al., 2018), and Uruguay (Bucheli et al., 2014). 4 The World Bank classifies countries as follows. Low-income: US $\$ 1,025$ or less; lower-middle-income: US $\$ 1,026-4,035$; upper-middle-income: US\$4,036-12,475; and, high-income: US\$12,476 or more. The classification uses Gross National Income per capita calculated with the World Bank Atlas Method, September 2016: http://data.worldbank.org/about/countryand-lending-groups.

${ }^{5}$ Launched first as a project in 2008, the Commitment to Equity Institute (CEQI) at Tulane University was created in 2015 with the generous support of the Bill and Melinda Gates Foundation.
} 
As for the impact of specific instruments on inequality, direct taxes are equalizing except in Colombia, Ghana and Tanzania, direct transfers are always equalizing, indirect taxes are equalizing (which may come as a surprise) except in Colombia, Georgia, Indonesia, Jordan and Russia, indirect subsidies are equalizing except in Armenia, Ghana, and Tanzania, and education and health spending are always equalizing except health spending in Jordan. While by definition all taxes are poverty increasing as long as the poor and near poor pay them, consumption taxes are the main culprits of fiscally-induced impoverishment.

The paper is organized as follows. Section 2 includes a brief description of the fiscal incidence methodology. Section 3 presents spending allocation and revenue raising patterns for the twenty-five countries. Sections 4 and 5 discuss the impact of fiscal policy on inequality and poverty, respectively. Section 6 examines the pro-poorness of government spending on education and health. Section 7 concludes.

\section{FISCAL INCIDENCE ANALYSIS: METHODOLOGICAL HIGHLIGHTS ${ }^{6}$}

Fiscal incidence analysis is used to assess the distributional impacts of a country's taxes and transfers. Essentially, fiscal incidence analysis consists of allocating taxes (personal income tax and consumption taxes, in particular) and public spending (social spending in particular) to households or individuals so that one can compare incomes before taxes and transfers with incomes after taxes and transfers. Transfers include both cash transfers and benefits in kind such as free government services in education and healthcare. Transfers also include consumption subsidies such as food, electricity and fuel subsidies.

As with any fiscal incidence study, let's start by defining the basic income concepts. Here there are four: market, disposable, consumable and final income. ${ }^{8}$ These income concepts are described below and summarized in Diagram 1.

Market income is total current income before direct taxes, equal to the sum of gross (pre-tax) wages and salaries in the formal and informal sectors (also known as earned income), income from capital (dividends, interest, profits, rents, etc.) in the formal and informal sectors (excludes capital gains and gifts), consumption of own production, ${ }^{10}$ imputed rent for owner occupied housing, and private transfers (remittances, pensions from private schemes and other private transfers such as alimony). The welfare indicator used in the fiscal incidence analysis is income per capita, ${ }^{11}$ except for Ethiopia, Ghana, Indonesia, Jordan, Sri Lanka and Tunisia in which the welfare indicator is consumption per capita. ${ }^{12}$ In

\footnotetext{
${ }^{6}$ This section is based on Lustig and Higgins (2013).

7 In addition to the studies cited here and other studies in www.commitmentoequity.org, see, for example, Förster and Whiteford (2009), Immervoll and Richardson (2011) and OECD (2011).

8 In the case of Indonesia, the surveys do not have income data so the incidence analysis is based on assuming consumption equals disposable income.

${ }^{9}$ Market income is sometimes called primary or original income.

${ }^{10}$ Except for the cases of Bolivia, Ecuador, Costa Rica, Honduras, Sri Lanka and South Africa, whose data on auto-consumption (also called own-production or self-consumption) was not considered in the market income definition.

${ }^{11}$ No adjustments were made for household composition or economies of scale. For Brazil, Higgins et al. (2016) analyze the impact of taxes and transfers using equivalized income.

${ }^{12}$ In Indonesia, the fiscal incidence analysis was carried out adjusting for spatial price differences because they are considered to be very large.
} 
these countries, disposable income was assumed to equal consumption and market income was generated "backwards" applying a "net to gross" conversion. ${ }^{13}$

Disposable income is defined as market income minus direct personal income taxes on all income sources (included in market income) that are subject to taxation plus direct government transfers (mainly cash transfers but can include near cash transfers such as food transfers, free textbooks and school uniforms). The Indonesian survey does not include individuals with income levels beyond the threshold at which direct taxes begin to apply (see Afkar et al. 2017), so there is no calculation for the incidence of personal income taxes. In the data for South Africa, free basic services are considered as direct transfers. ${ }^{14}$

Consumable income is defined as disposable income plus indirect subsidies (e.g., food and energy price subsidies) minus indirect taxes (e.g., value added taxes, excise taxes, sales taxes, etc.).

Final income is defined as consumable income plus government transfers in the form of free or subsidized services in education and health valued at average cost of provision ${ }^{15}$ (minus co-payments or user fees, when they exist).

One area in which there is no clear consensus is how pensions from a pay-as-you-go contributory system should be treated. Arguments exist in favor of both treating contributory pensions as deferred income ${ }^{16}$ or as a government transfer, especially in systems with a large subsidized component. ${ }^{17}$ Since this is an unresolved issue, the studies analyzed here present results for both scenarios with the exception of a few countries described below. One scenario treats social insurance contributory pensions (herewith called contributory pensions) as deferred income (which in practice means that they are added to market income to generate the pre-fiscal income). The other scenario treats these pensions as any other cash transfer from the government. ${ }^{18}$ For consistency, when pensions are treated as deferred income, the contributions by individuals are included under savings (they are mandatory savings) while when they are treated as government transfers, the contributions are considered a direct tax.

It is important to note that the treatment of contributory pensions not only affects the amount of redistributive spending and how it gets redistributed, but also the ranking of households by original income or pre-fiscal income. For example, in the scenario in which contributory pensions are considered a government transfer, households whose main (or sole) source of income is pensions will have close to (or just) zero income before taxes and transfers and hence will be ranked at the bottom of the income scale. When contributory pensions are treated as deferred income, in contrast, households who receive contributory pensions will be placed at a (sometimes considerably) higher position in the income scale. Thus, the treatment of contributory pensions in the incidence exercise could have significant implications for the order of magnitude of the pre-fiscal and post-fiscal inequality and poverty indicators.

\footnotetext{
13 See Lustig and Higgins (2013) and Lustig, editor (2018) for details. This method was suggested by Immervoll and O'Donoghue (2001).

${ }^{14}$ These free basic services are delivered by municipal governments sometimes at zero cost and sometimes at a subsidized price. Given the difficulty in determining which case applies for households included in the survey, the analysis was carried out in both ways. Results in which the free basic services are considered a subsidy are available upon request.

15 See, for example, Sahn and Younger (2000).

16 Breceda et al. (2008); Immervoll et al. (2009).

${ }^{17}$ Goñi et al. (2011); Immervoll et al. (2009); Lindert et al. (2006).

${ }^{18}$ Immervoll et al. (2009) do the analysis under these two scenarios as well.
} 
The only contributory pensions in South Africa are for public servants who must belong to the Government Employees Pension Fund (GEPF). Since the government made no transfers to the GEPF in 2010/11, there is no scenario in which contributory pensions are treated as a transfer. The same occurs in the cases of Ethiopia, Ghana and Tanzania. The only contributory pensions in Sri Lanka are for public servants and income from pensions has been considered as part of the public employees' labor contract, rather than a transfer in spite of the fact that the funding comes from general revenues. In other words, for Ethiopia, Ghana, South Africa, Sri Lanka and Tanzania, there is no scenario in which contributory pensions are considered as a transfer. Georgia has a non-contributory public pension scheme only, therefore, pensions are treated as a transfer, and both scenarios have the same results.

In the construction of final income, the method for education spending consists of imputing a value to the benefit accrued to an individual of going to public school which is equal to the per beneficiary input costs obtained from administrative data: for example, the average government expenditure per primary school student obtained from administrative data is allocated to the households based on how many children are reported attending public school at the primary level. In the case of health, the approach was analogous: the benefit of receiving healthcare in a public facility is equal to the average cost to the government of delivering healthcare services to the beneficiaries. In the case of Colombia, however, the method used was to impute the insurance value to beneficiary households rather than base the valuation on utilization of healthcare services.

This approach to valuing education and healthcare services amounts to asking the following question: how much would the income of a household have to be increased if it had to pay for the free or subsidized public service (or the insurance value in the cases in which this applies to healthcare benefits) at the full cost to the government? Such an approach ignores the fact that consumers may value services quite differently from what they cost. Given the limitations of available data, however, the cost of provision method is the best one can do for now. ${ }^{19}$ For the readers who think that attaching a value to education and health services based on government costs is not accurate, the method applied here is equivalent to using a simple binary indicator of whether or not the individual uses the government service. $^{20} 21$

\footnotetext{
${ }_{19}$ By using averages, it also ignores differences across income groups and regions: e.g., governments may spend less (or more) per pupil or patient in poorer areas of a country. Some studies in the CEQ project adjusted for regional differences. For example, Brazil's health spending was based on regional specific averages.

${ }^{20}$ This is of course only true within a level of education. A concentration coefficient for total non-tertiary education, for example, where the latter is calculated as the sum of the different spending amounts by level, is not equivalent to the binary indicator method.

${ }^{21}$ In order to avoid exaggerating the effect of government services on inequality, the totals for education and health spending in the studies reported here were scaled-down so that their proportion to disposable income in the national accounts are the same as those observed using data from the household surveys.
} 


\section{DIAGRAM 1: BASIC INCOME CONCEPTS}

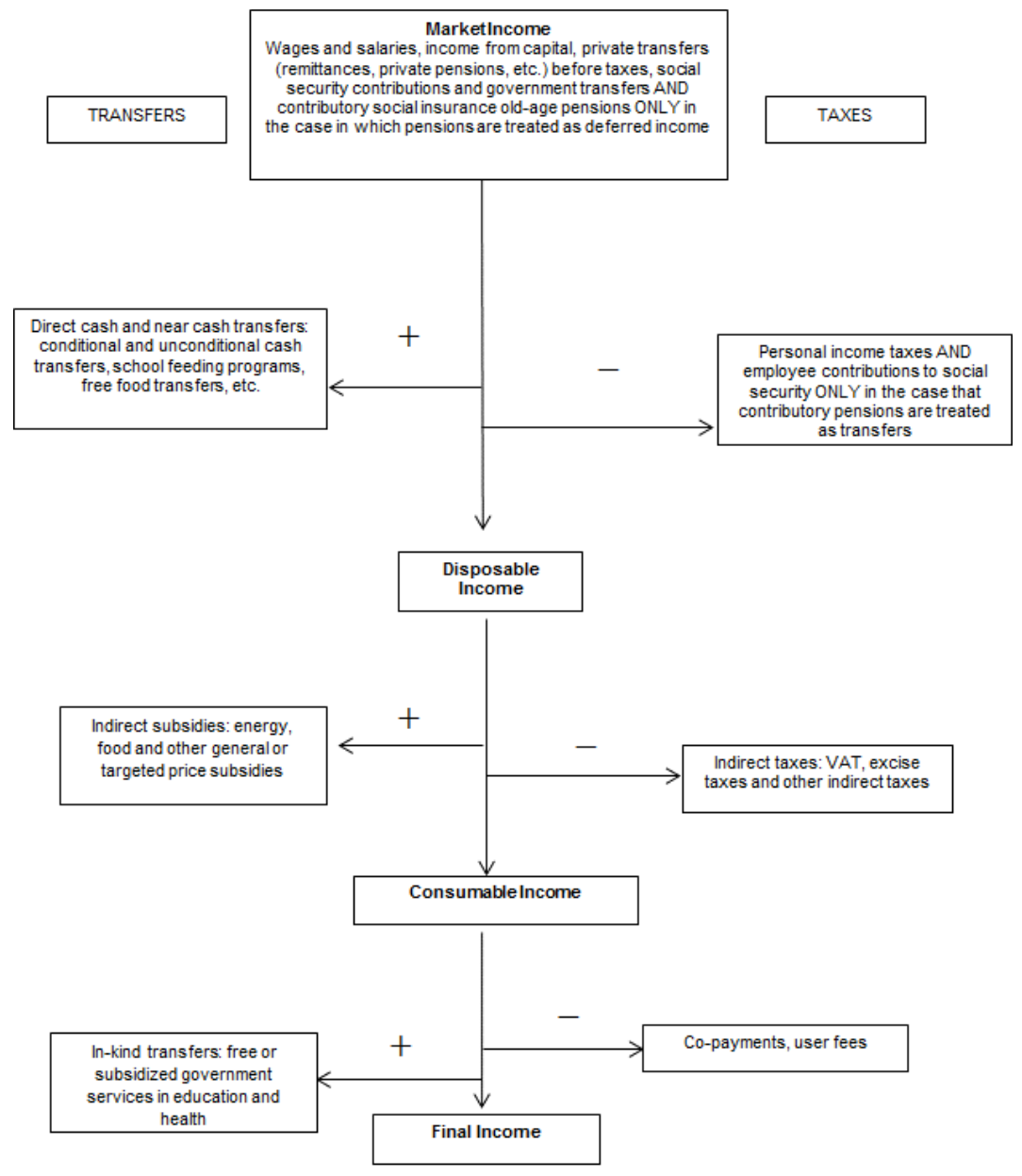

Source: Lustig and Higgins (2018)

The fiscal incidence analysis used here is point-in-time and does not incorporate behavioral or general equilibrium effects. That is, no claim is made that the original or market income equals the true counterfactual income in the absence of taxes and transfers. It is a first-order approximation that measures the average incidence of fiscal interventions. However, the analysis is not a mechanically applied accounting exercise. The incidence of taxes is the economic rather than statutory incidence. It is assumed that individual income taxes and contributions both by employees and employers, for instance, are borne by labor in the formal sector. Individuals who are not contributing to social security are assumed to pay neither direct taxes nor contributions. Consumption taxes are fully shifted forward to consumers. In the case of consumption taxes, the analyses take into account the lower incidence associated with ownconsumption, rural markets and informality.

The household surveys used in the country studies are the following (the I and C refers to the fact that the studies were either income- or consumption-based, respectively; see Lustig and Higgins, 2013 for 
details): Argentina (I): Encuesta Nacional de Gasto de los Hogares, 2012-13; Armenia (I): Integrated Living Conditions Survey, 2011; Bolivia (I): Encuesta de Hogares, 2009; Brazil (I): Pesquisa de Orçamentos Familiares, 2008-2009; Chile (I): Encuesta de Caracterización Social (CASEN), 2013; Colombia (I): Encuesta de Calidad de Vida, 2010; Costa Rica (I): Encuesta Nacional de Hogares, 2010; Dominican Republic (I): Encuesta Nacional de Ingresos y Gastos de los Hogares, 2006-2007; Ecuador (I): Encuesta Nacional de Ingresos y Gastos de los Hogares Urbano y Rural, 2011-2012; El Salvador (I): Encuesta de Hogares de Propósitos Múltiples, 2011; Ethiopia (C): Household Consumption Expediture Survey, 2010 -2011 and Welfare Monitoring Survey, 2011; Georgia (I): Integrated Household Survey, 2013; Ghana (C): Living Standards Survey, 2012-2013; Guatemala (I): Encuesta Nacional de Ingresos y Gastos Familiares, 2009-2010 and Encuesta Nacional de Condiciones de Vida, 2011; Honduras (I): Encuesta Permanente de Hogares de Propósitos Múltiples, 2011; Indonesia (C): Survei Sosial-Ekonomi Nasional, 2012; Jordan (C): Household Expenditure and Income Survey, 2010-2011; Mexico (I): Encuesta Nacional de Ingreso y Gasto de los Hogares, 2010; Perú (I): Encuesta Nacional de Hogares, 2009; Russia (I): Russian Longitudinal Monitoring Survey of Higher School of Economics, 2010; South Africa (I): Income and Expenditure Survey, 2010-2011; Sri Lanka (C): Household Income and Expenditure Survey, 2009-2010; Tanzania (C): Household Budget Survey, 2011-2012; Tunisia (C):

National Survey of Consumption and Household Living Standards, 2010; Uruguay (I): Encuesta Continua de Hogares, 2009. ${ }^{22}$

\section{TAXES AND PUBLIC SPENDING: LEVELS AND COMPOSITION}

The redistributive potential of a country is determined first and foremost by the size and composition of its budget and how government spending is financed. Figure 1 shows government revenues as a share of GDP for around 2010. The revenue collection patterns are heterogeneous. Mexico relies heavily on nontax revenues (from the state-owned oil company), followed by Ecuador, Brazil, Jordan and Peru. In general, indirect taxes are the largest component of government revenues (as a share of GDP), except for Mexico and Ecuador (where nontax revenues from oil-producing companies is the largest) and South Africa (direct taxes is the largest).

\footnotetext{
22 Note that empirically one often starts from a concept different from market income. In many income-based surveys, reported income corresponds to (or is assumed to be) market income net of direct taxes. In consumption-based surveys, there is often no reported income at all. In those cases, the incidence analysis assumed that consumption is equivalent to disposable income.
} 


\section{FIGURE 1: SIZE AND COMPOSITION OF GOVERNMENT REVENUES (as a \% of GDP; CIRCA 2010)}

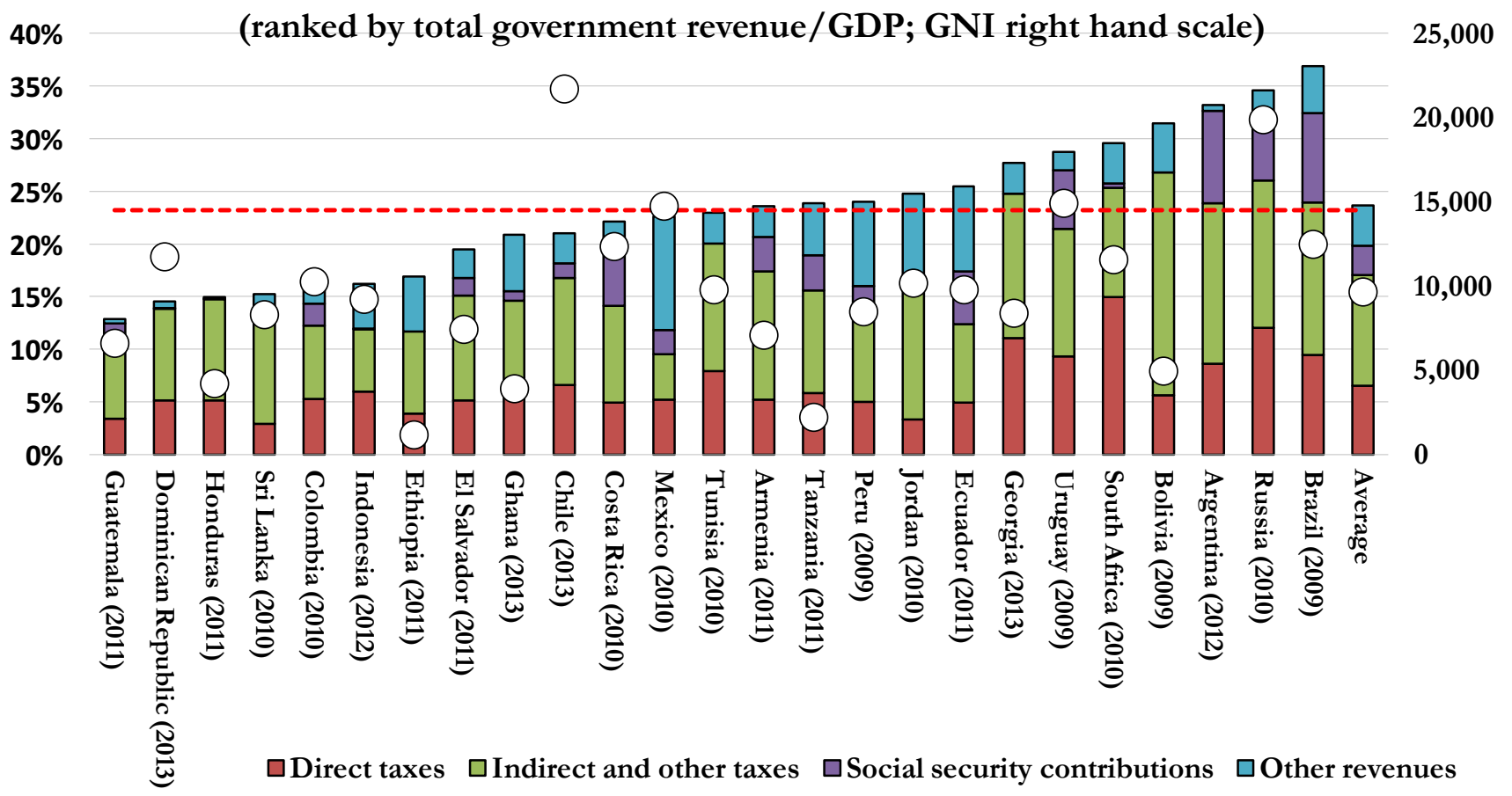

Source: CEQ Institute's Data Center on Fiscal Redistribution. Based on the following Master Workbooks of Results. Argentina: Rossignolo, 2017; Armenia: Younger and Khachatryan, 2014; Bolivia: Paz-Arauco et al., 2014b; Brazil: Higgins and Pereira, 2017; Chile: Martínez-Aguilar and Ortiz-Juarez, 2016; Colombia: Melendez and Martínez, 2015; Costa Rica: Sauma and Trejos, 2014b; Dominican Republic: Aristy-Escuder et al., 2016; Ecuador: Llerena et al., 2017; El Salvador: Beneke et al., 2014; Ethiopia: Hill et al., 2014; Georgia: Cancho and Bondarenko, 2015; Ghana: Younger et al., 2016; Guatemala: Cabrera and Morán, 2015; Honduras: Castañeda and Espino, 2015; Indonesia: Afkar, Jellema and Wai-Poi, 2015; Jordan: Abdel-Halim et al., 2016; Mexico: Scott, 2013; Peru: Jaramillo, 2015; Russia: Malytsin and Popova, 2016; South Africa: Inchauste et al., 2016; Sri Lanka: Arunatilake et al., 2016; Tanzania: Younger et al., 2016b; Tunisia: Jouni, et al., 2015; Uruguay: Bucheli et al., 2014.

Notes: Year of household survey in parenthesis. Data shown here is administrative data reported by the studies cited above and the numbers do not necessarily coincide with those of multilateral organizations. Gross National Income per capita on right axis is in 2011 PPP from World Development Indicators, August 29th, 2016: http://data.worldbank.org/indicator/NY.GNP.PCAP.PP.CD.

Figure 2 shows the level and composition of primary and social spending plus contributory pensions (panel A), and the composition of social spending for the following categories: direct transfers, education, health, and other social spending around 2010 (panel B). On average, the twenty-five lowincome and middle-income countries analysed here allocate 10.4 percent of GDP to social spending while the advanced countries in the OECD group, allocate 18.8 percent of GDP, that is, almost twice as much. The twenty-five countries on average spend 1.8 percent of GDP on direct transfers, 4.5 percent on education and 3.0 percent on health. In comparison, the OECD countries, on average, spend 4.4 percent of GDP on direct transfers, 5.3 percent on education and 6.2 percent on health. The largest 
difference between the OECD group and our sample occurs in direct transfers. Regarding pensions (includes contributory pensions only and not special social pensions, which are part of direct transfers), the twenty-five low-income and middle-income countries spend 3.4 percent of their GDP while OECD countries, spend 7.9 percent.

FIGURE 2: SIZE AND COMPOSITION OF PRIMARY AND SOCIAL SPENDING PLUS CONTRIBUTORY PENSIONS (AS A \% OF GDP; CIRCA 2010)

Panel A: Primary and social spending plus contributory pensions as a \% of GDP

(ranked by primary spending / GDP; GNI right hand scale)

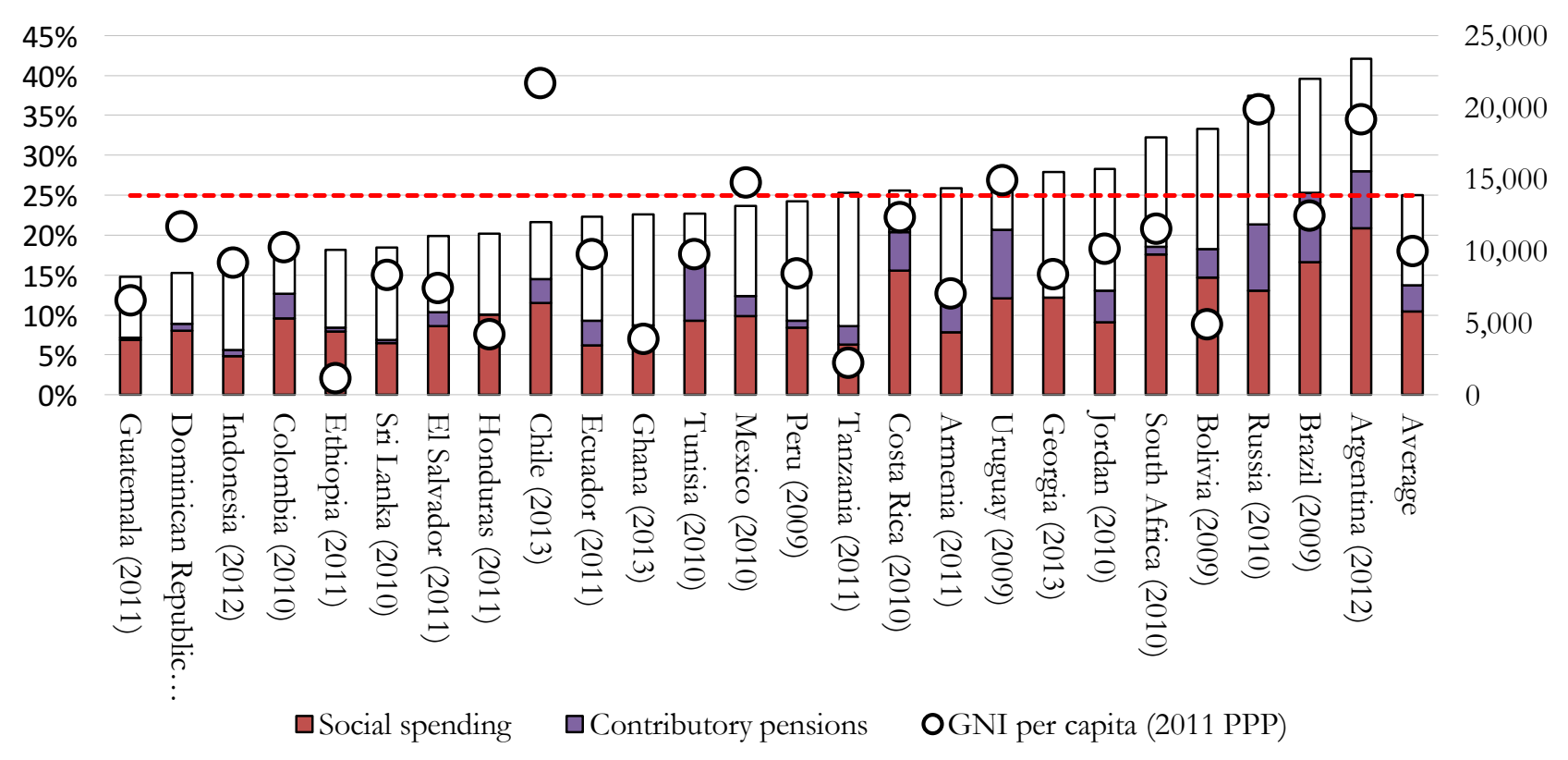


Panel B: Composition of social spending plus contributory pensions as a \% of GDP

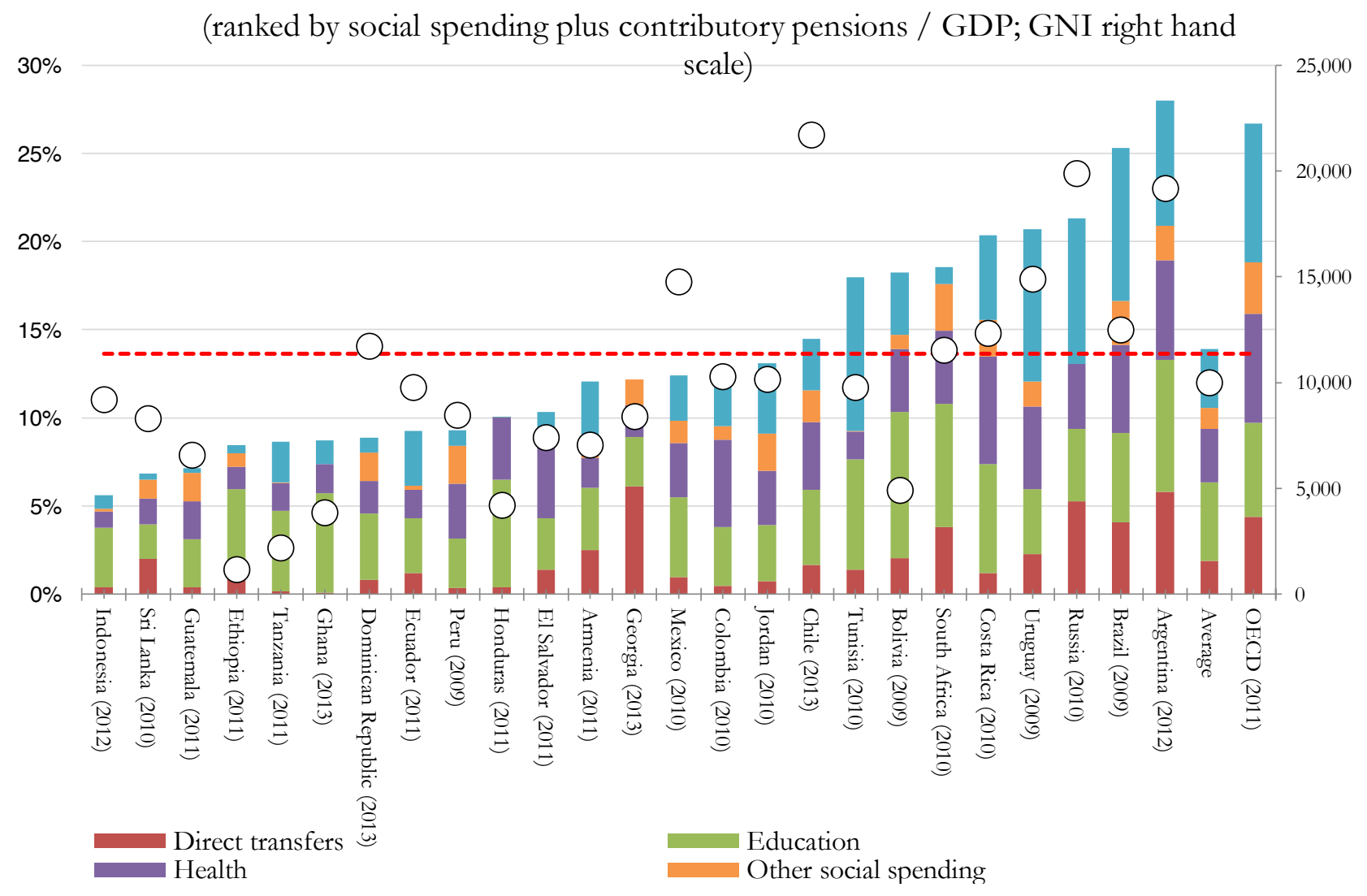

Source: CEQ Institute's Data Center on Fiscal Redistribution. Based on the following Master Workbooks of Results. Argentina: Rossignolo, 2017; Armenia: Younger and Khachatryan, 2014; Bolivia: Paz-Arauco et al., 2014b; Brazil: Higgins and Pereira, 2017; Chile: Martínez-Aguilar and Ortiz-Juarez, 2016; Colombia: Melendez and Martínez, 2015; Costa Rica: Sauma and Trejos, 2014b; Dominican Republic: Aristy-Escuder et al., 2016; Ecuador: Llerena et al., 2017; El Salvador: Beneke et al., 2014; Ethiopia: Hill et al., 2014; Georgia: Cancho and Bondarenko, 2015; Ghana: Younger et al., 2016; Guatemala: Cabrera and Morán, 2015; Honduras: Castañeda and Espino, 2015; Indonesia: Afkar, Jellema and Wai-Poi, 2015; Jordan: Abdel-Halim et al., 2016; Mexico: Scott, 2013; Peru: Jaramillo, 2015; Russia: Malytsin and Popova, 2016; South Africa: Inchauste et al., 2016; Sri Lanka: Arunatilake et al., 2016; Tanzania: Younger et al., 2016b; Tunisia: Jouni, et al., 2015; Uruguay: Bucheli et al., 2014.

Notes: year of household survey in parenthesis. Data shown here is administrative data reported by the studies cited above and the numbers do not necessarily coincide with those of multilateral organizations. Gross National Income per capita on right axis is in 2011 PPP from World Development Indicators, August 29 th 2016 :

http://data.worldbank.org/indicator/NY.GNP.PCAP.PP.CD.

The scenario for South Africa assumed free basic services are direct transfers. For Tanzania, fiscal year runs from July 2011 June 2012. Figure for OECD average (includes only advanced countries) was directly provided by the statistical office of the organization.

Given the size of social spending (from highest to lowest), Argentina, Brazil, Uruguay, Russia, Costa Rica, Bolivia, and South Africa have the largest amount of resources at their disposal to engage in fiscal redistribution. At the other end of the spectrum are Indonesia, Sri Lanka and Guatemala. Whether the 
first group achieve their higher redistributive potential, however, depends on how the burden of taxation and the benefits of social spending is distributed. This shall be discussed below. First, however, the next section presents a brief description of the fiscal incidence methodology utilized in the twenty-five studies.

\section{THE REDISTRIBUTIVE EFFECT OF FISCAL POLICY}

A typical indicator of the redistributive effect of fiscal policy is the difference between the market income Gini and the Gini for income after taxes and transfers. ${ }^{23}$ If the redistributive effect is positive (negative), fiscal policy is equalizing (unequalizing).

Figure 3 presents the Gini coefficient for market income and the other three income concepts shown in Diagram 1: disposable, consumable and final income. ${ }^{24}$ In broad terms, disposable income measures how much income individuals may spend on goods and services (and save, including mandatory savings such as contributions to a public pensions system that is actuarially fair). Consumable income measures how much individuals are able to actually consume. For example, a given level of disposable income--even if consumed in full--could mean different levels of actual consumption depending on the size of indirect taxes and subsidies. Final income includes the value of public services in education and health if individuals would have had to pay for those services at the average cost to the government. Based on the fact that contributory pensions can be treated as deferred income or as a direct transfer, here all the calculations are presented for two scenarios: one with contributory pensions included in market income and another with them as government transfers. For consistency, remember that in the first scenario contributions to the system are treated as mandatory savings and in the second as a tax.

\footnotetext{
${ }_{23}$ All the theoretical derivations that link changes in inequality to the progressivity of fiscal interventions have been derived based on the socalled family of S-Gini indicators, of which the Gini coefficient is one case. See for example, Duclos and Araar (2006). While one can calculate the impact of fiscal policy on inequality using other indicators (and one should), it will not be possible to link them to the progressivity of the interventions.

${ }^{24}$ Other measures of inequality such as the Theil index or the 90/10 ratio are available in the individual studies. Requests should be addressed directly to the authors.
} 


\section{FIGURE 3: FISCAL POLICY AND INEQUALITY (CIRCA 2010): GINI COEFFICIENT FOR MARKET, DISPOSABLE, CONSUMABLE AND FINAL INCOME}

Panel A: Contributory pensions as deferred income

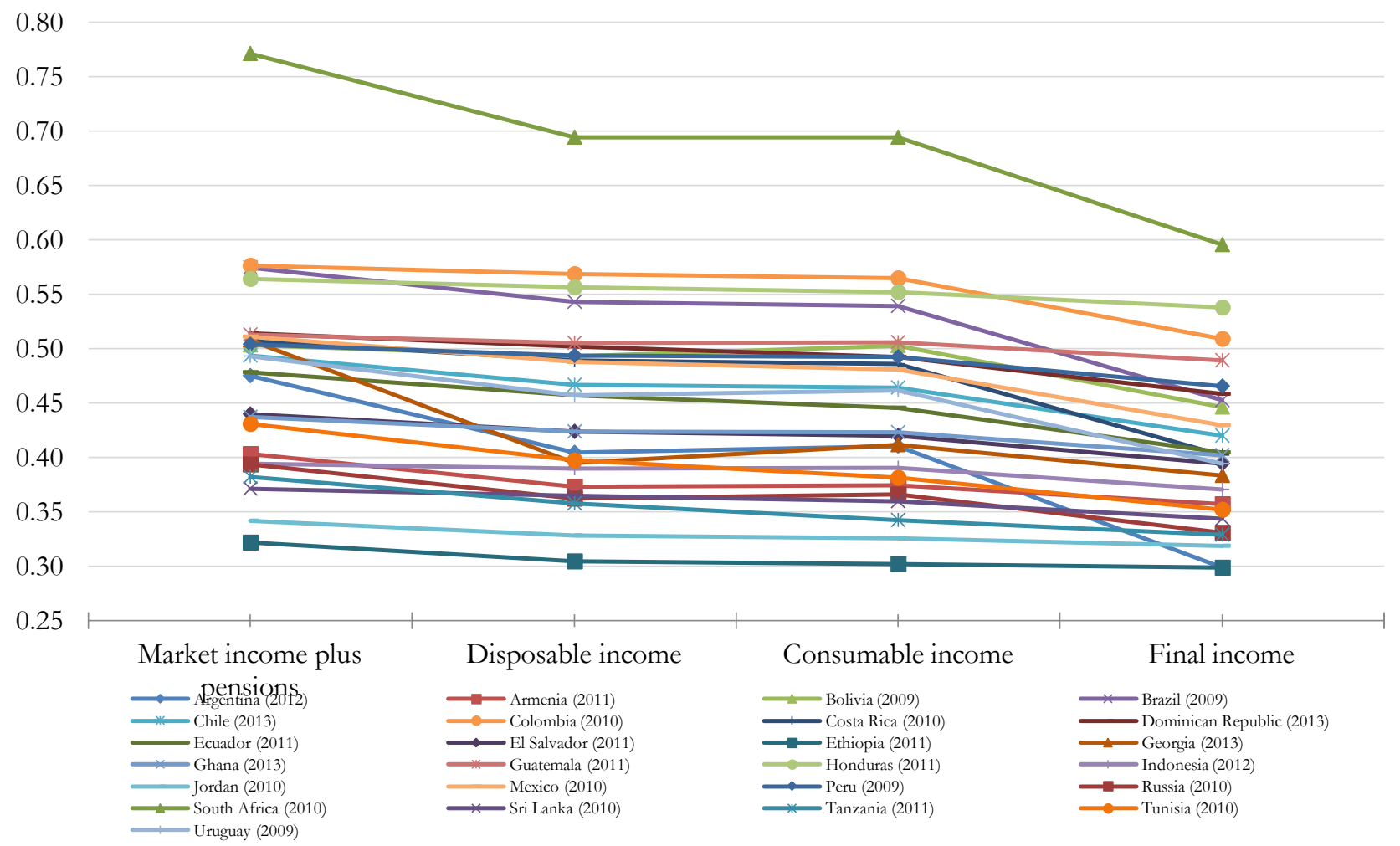


Panel B: Contributory pensions as transfers

0.65

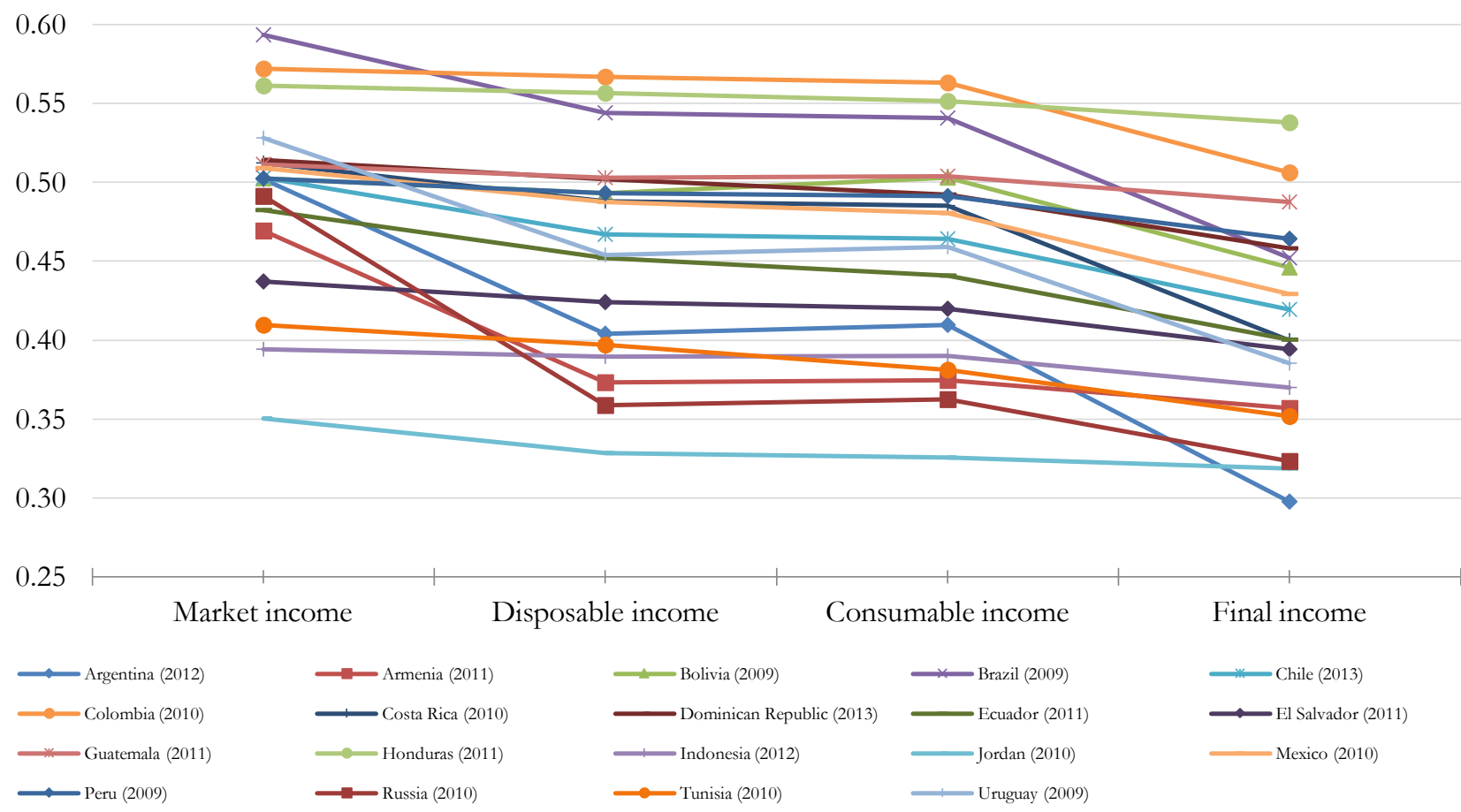

Source: CEQ Institute's Data Center on Fiscal Redistribution. Based on the following Master Workbooks of Results. Argentina: Rossignolo, 2017; Armenia: Younger and Khachatryan, 2014; Bolivia: Paz-Arauco et al., 2014b; Brazil: Higgins and Pereira, 2017; Chile: MartínezAguilar and Ortiz-Juarez, 2016; Colombia: Melendez and Martínez, 2015; Costa Rica: Sauma and Trejos, 2014b; Dominican Republic: Aristy-Escuder et al., 2016; Ecuador: Llerena et al., 2017; El Salvador: Beneke et al., 2014; Ethiopia: Hill et al., 2014; Georgia: Cancho and Bondarenko, 2015; Ghana: Younger et al., 2016; Guatemala: Cabrera and Morán, 2015; Honduras: Castañeda and Espino, 2015; Indonesia: Afkar, Jellema and Wai-Poi, 2015; Jordan: Abdel-Halim et al., 2016; Mexico: Scott, 2013; Peru: Jaramillo, 2015; Russia: Malytsin and Popova, 2016; South Africa: Inchauste et al., 2016; Sri Lanka: Arunatilake et al., 2016; Tanzania: Younger et al., 2016b; Tunisia: Jouni, et al., 2015; Uruguay: Bucheli et al., 2014.

Notes: Bolivia does not have personal income taxes. In Bolivia, Costa Rica, Ecuador, Honduras, South Africa, and Sri Lanka, market income does not include consumption of own production because the data was either not available or not reliable. For Brazil, the results for the analysis presented here differ from the results published in Higgins and Pereira (2014) because the latter include taxes on services (ISS), on goods and services to finance pensions (CONFINS) and to finance Social Workers (PIS), while the results presented here do not include them. Post publishing the mentioned paper, the authors concluded that the source for these taxes was not reliable. Gini coefficients for Chile are estimated here using total income and, thus, differ from official figures of inequality which are estimated using monetary income (i.e., official figures exclude owner's occupied imputed rent). In South Africa, the results presented here assume that free basic services are a direct transfer. In Armenia, Costa Rica, Peru, South Africa and Uruguay, there are no indirect subsidies. For Dominican Republic, the study analyzes the effects of fiscal policy in 2013, but the household income and expenditure survey dates back to 2006-07. For Indonesia, the fiscal incidence analysis was carried out adjusting for spatial price differences. Personal income taxes are assumed to be zero because the vast majority of households have implied market incomes below the tax threshold. The only contributory pensions in South Africa are for public servants who must belong to the Government Employees Pension Fund (GEPF). Since the government made no transfers to the GEPF in 2010/11, there is no scenario with contributory pensions as transfer. The same occurs in the cases of Ethiopia, Ghana and Tanzania. The only contributory pensions in Sri Lanka are for public servants and income from pensions has been considered as part of the public employees' labor contract, rather than a transfer in spite of the fact that the funding comes from general revenues. In other words, for Ethiopia, Ghana, South Africa, Sri Lanka and Tanzania, there is no scenario in which contributory pensions are considered as a transfer. Georgia has a noncontributory public pension scheme only and, therefore, they are only treated as a transfer. In all these cases, the scenario is the same in both panels. 
As can be observed, in Honduras, Guatemala and Indonesia, fiscal income redistribution is quite limited while in Argentina, Georgia, South Africa and Brazil, it is of a relevant magnitude. Colombia is in the middle of these two groups. One can observe that South Africa is the country that redistributes the most but it still remains the most unequal of all twenty-five. It is interesting to note that although Brazil and Colombia start out with similar market income inequality, Brazil reduces inequality considerably while Colombia does not. Similarly, Mexico, Costa Rica and Guatemala start out with similar levels of market income inequality but Mexico and Costa Rica reduce inequality by more. Ethiopia is the less unequal of all twenty-five and fiscal redistribution is also the smallest in order of magnitude. In almost all cases, the largest change in inequality occurs between consumable and final income. This is not surprising given the fact that governments spend more on education and health than on direct transfers and pensions. However, one should not make sweeping conclusions from this result because-as discussed above-inkind transfers are valued at average government cost which is not really a measure of the "true" value of these services to the individuals who use them.

Panels A and B in Figure 3 show that the patterns of inequality decline are similar whether one looks at the scenario in which contributory pensions are considered deferred income (and, thus, part of market income) or with pensions as transfers. In Argentina, Armenia, Brazil, Russia, and Uruguay, the redistributive effect is considerably larger when contributory pensions are treated as a transfer. These are countries with higher coverage and an older population. In Chile, Costa Rica, Ecuador, and Jordan, the effect is larger but very slightly. Interestingly, in Bolivia, Colombia, El Salvador, Honduras, Mexico, Nicaragua, and Tunisia, the redistributive effect is smaller when contributory pensions are considered a government transfer versus deferred income.

\section{i The redistributive effect of fiscal policy: do more unequal countries redistribute more?}

Income redistribution tends to be higher in more unequal countries to start with: redistribution is considerable higher in countries with higher market income inequality such as South Africa, than in countries with relatively lower inequality, such as Sri Lanka and Indonesia (see Figure 4, Panel A). Among these countries, Honduras and Colombia stand as an outlier with a rather low degree of redistribution given its high level of market income inequality. Previous studies also generally suggest a positive correlation between market income inequality and measures of redistribution. Lustig (2015) finds this in an analysis for thirteen developing countries. An OECD study (2011, Chapter 7) illustrates that more market income inequality tends to be associated with higher redistribution, for a sub-set of OECD countries, both within countries (over time) and across countries.

Differences in redistribution change the relative ranking of countries by inequality level. Figure 5, Panel A displays the levels of income inequality before (horizontal axis) and after (vertical axis) accounting for fiscal policies. Since all data points fall below the diagonal, fiscal policies reduce inequality in all countries. South Africa continues to be the most unequal country and Ethiopia the least unequal country based on income before or after fiscal policy. However, due to lower redistribution, Peru ends up being more unequal than Brazil once fiscal policies are considered while the opposite was true when inequality is measured with market income. 
FIGURE 4: INITIAL INEQUALITY AND FISCAL REDISTRIBUTION, CIRCA 2010

Panel A: Redistribution and market income plus contributory pensions inequality (Contributory pensions as deferred income)

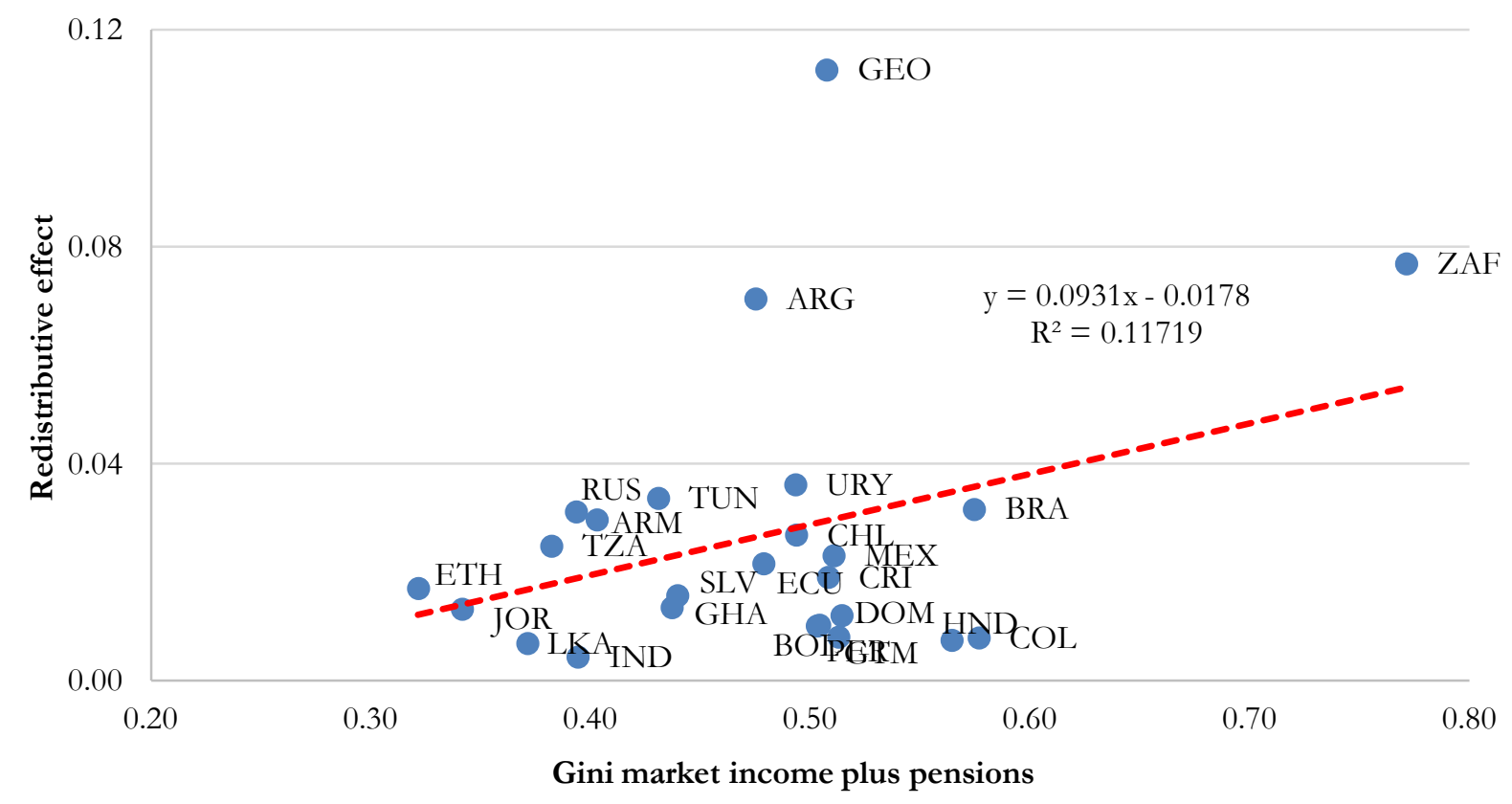


Panel B: Redistribution and market income inequality (Contributory pensions as transfers)

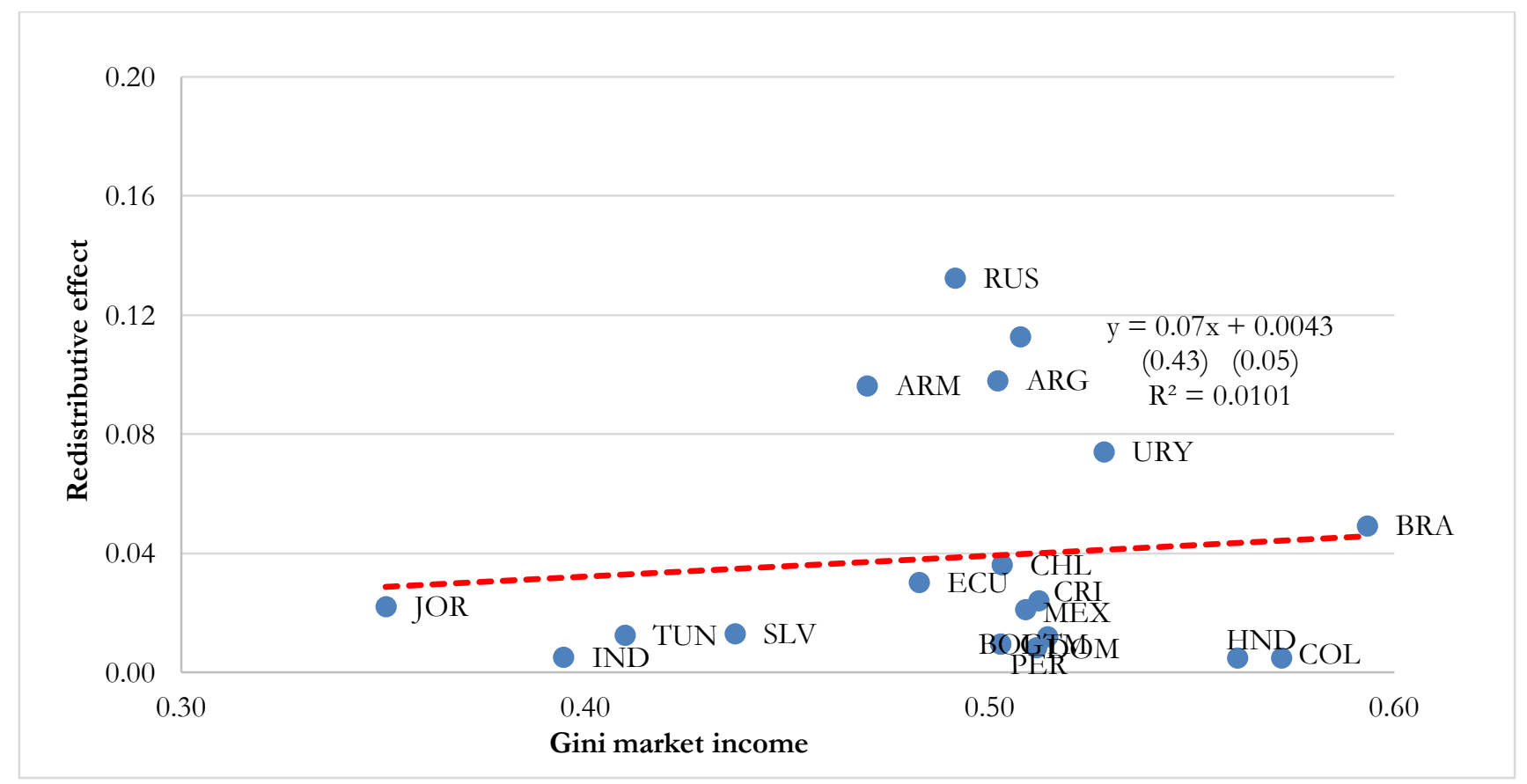

Source: CEQ Institute's Data Center on Fiscal Redistribution. Based on the following Master Workbooks of Results. Argentina: Rossignolo, 2017; Armenia: Younger and Khachatryan, 2014; Bolivia: Paz-Arauco et al., 2014b; Brazil: Higgins and Pereira, 2017; Chile: Martínez-Aguilar and Ortiz-Juarez, 2016; Colombia: Melendez and Martínez, 2015; Costa Rica: Sauma and Trejos, 2014b; Dominican Republic: Aristy-Escuder et al., 2016; Ecuador: Llerena et al., 2017; El Salvador: Beneke et al., 2014; Ethiopia: Hill et al., 2014; Georgia: Cancho and Bondarenko, 2015; Ghana: Younger et al., 2016; Guatemala: Cabrera and Morán, 2015; Honduras: Castañeda and Espino, 2015; Indonesia: Afkar, Jellema and Wai-Poi, 2015; Jordan: Abdel-Halim et al., 2016; Mexico: Scott, 2013; Peru: Jaramillo, 2015; Russia: Malytsin and Popova, 2016; South Africa: Inchauste et al., 2016; Sri Lanka: Arunatilake et al., 2016; Tanzania: Younger et al., 2016b; Tunisia: Jouni, et al., 2015; Uruguay: Bucheli et al., 2014.

Notes: The dotted line in red is the slope obtained from a simple regression with the redistributive effect as a dependent variable. Redistributive effect is defined as the difference between Gini of market income plus contributory pensions and disposable income in Panel A and the difference between Gini of market income and disposable income in Panel B. In parentheses are t statistics. $* \mathrm{p}<0.1, * * \mathrm{p}<0.05, * * * \mathrm{p}<0.01$.

The number of countries in panel B is smaller because it does not include the countries for which-for different reasonsthere is no additional scenario in which contributory pensions were considered a transfer, namely: Ethiopia, Georgia, Ghana, South Africa, Sri Lanka and Tanzania. 


\section{FIGURE 5: MARKET INCOME PLUS CONTRIBUTORY PENSIONS GINI VERSUS}

FINAL INCOME GINI, CIRCA 2010

Panel A: Final income inequality and market income plus contributory pensions inequality (Contributory pensions as deferred income)

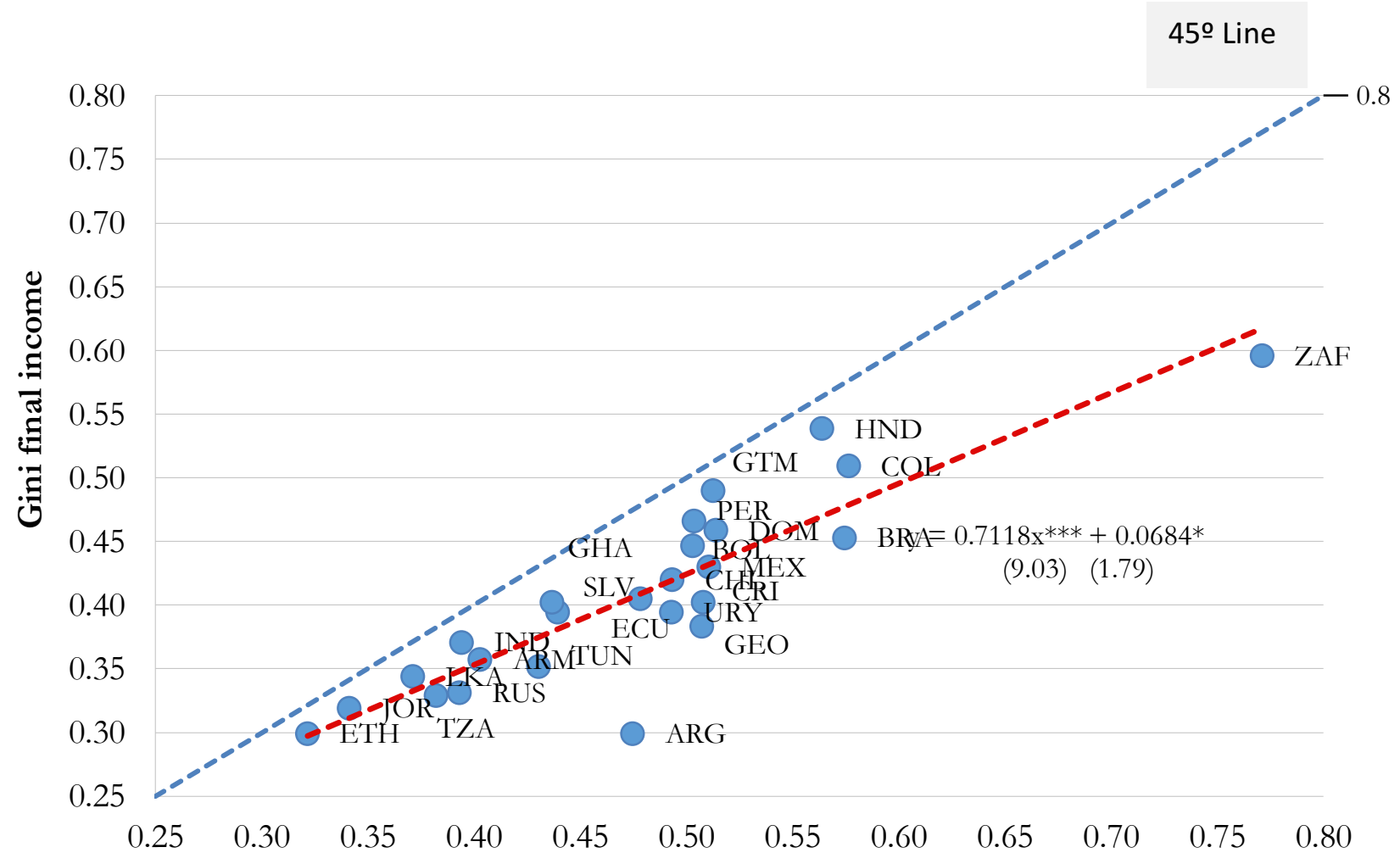

Gini market income plus pensions 
Panel B: Final income inequality and market income inequality (Contributory pensions as transfers)

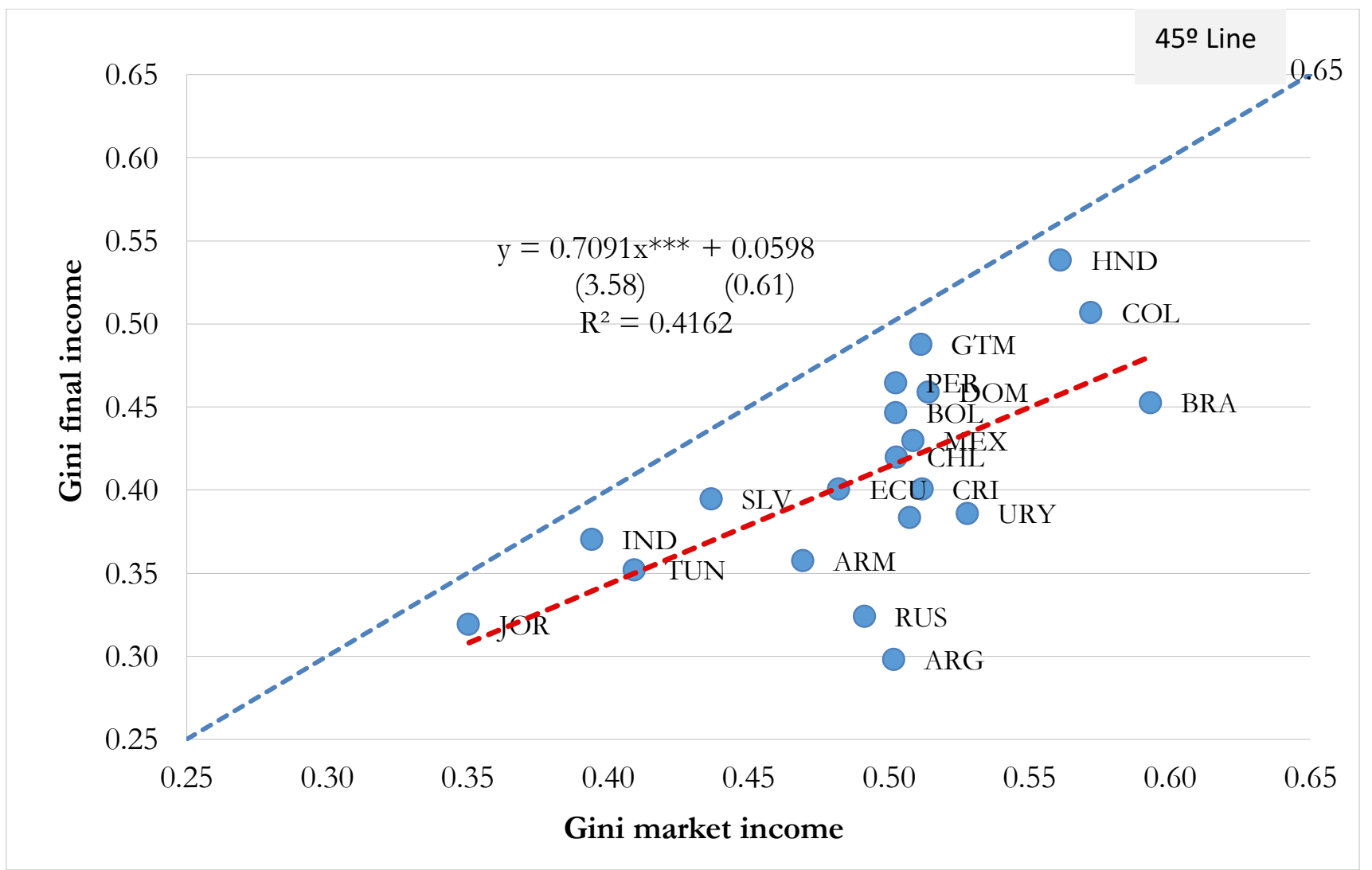

Source: CEQ Institute's Data Center on Fiscal Redistribution. Based on the following Master Workbooks of Results. Argentina: Rossignolo, 2017; Armenia: Younger and Khachatryan, 2014; Bolivia: Paz-Arauco et al., 2014b; Brazil: Higgins and Pereira, 2017; Chile: Martínez-Aguilar and Ortiz-Juarez, 2016; Colombia: Melendez and Martínez, 2015; Costa Rica: Sauma and Trejos, 2014b; Dominican Republic: Aristy-Escuder et al., 2016; Ecuador: Llerena et al., 2017; El Salvador: Beneke et al., 2014; Ethiopia: Hill et al., 2014; Georgia: Cancho and Bondarenko, 2015; Ghana: Younger et al., 2016; Guatemala: Cabrera and Morán, 2015; Honduras: Castañeda and Espino, 2015; Indonesia: Afkar, Jellema and Wai-Poi, 2015; Jordan: Abdel-Halim et al., 2016; Mexico: Scott, 2013; Peru: Jaramillo, 2015; Russia: Malytsin and Popova, 2016; South Africa: Inchauste et al., 2016; Sri Lanka: Arunatilake et al., 2016; Tanzania: Younger et al., 2016b; Tunisia: Jouni, et al., 2015; Uruguay: Bucheli et al., 2014.

Notes: The dotted line in red is the slope obtained from a simple regression with the final income Gini as a dependent variable. The dotted line in blue is a 45 degree line. In parentheses are t statistics. ${ }^{*} \mathrm{p}<0.1,{ }^{* *} \mathrm{p}<0.05,{ }^{* * *} \mathrm{p}<0.01$.

The number of countries in panel B is smaller because it does not include the countries for which-for different reasonsthere is no additional scenario in which contributory pensions were considered a transfer, namely: Ethiopia, Georgia, Ghana, South Africa, Sri Lanka and Tanzania.

As expected, the level of income redistribution and the size of the budget allocated to social spending (as a share of GDP) are associated. However, differences across countries suggest that institutional factors such as the composition and design of such policies and their interaction with socio-economic circumstances also affect the level of redistribution. Figure 6 presents the level of redistribution and social spending measured in the CEQ database. Redistribution is considerably larger in countries with high social spending, such as Argentina, Brazil, Costa Rica and South Africa, than in Indonesia, 
Guatemala and Sri Lanka, where social spending is more limited. Given the level of social spending, income redistribution is particularly high in South Africa.

\section{FIGURE 6: REDISTRIBUTION AND SOCIAL SPENDING, 2010}

Panel A: Contributory pensions as deferred income; from market income plus contributory pensions to final income

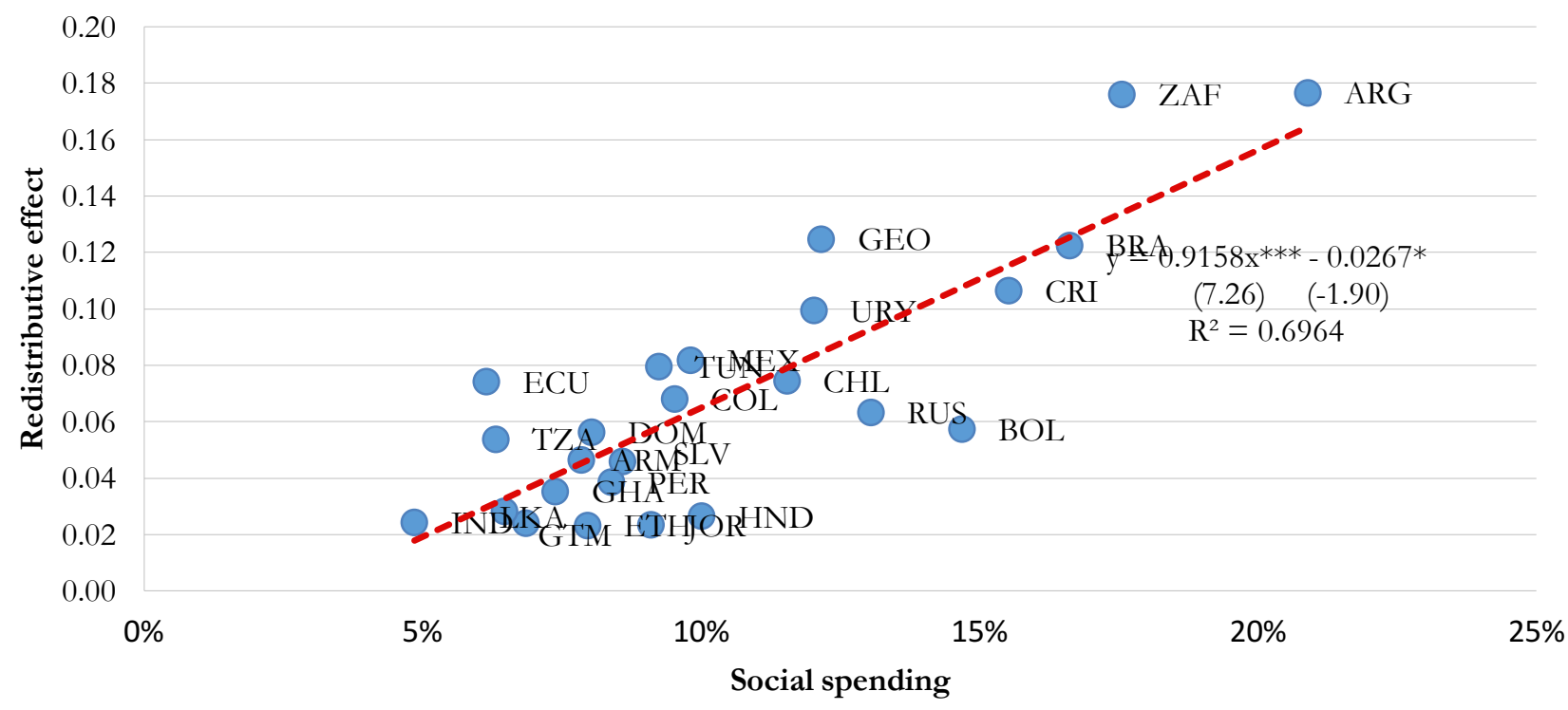


Panel B: Contributory pensions as transfers; from market income to final income

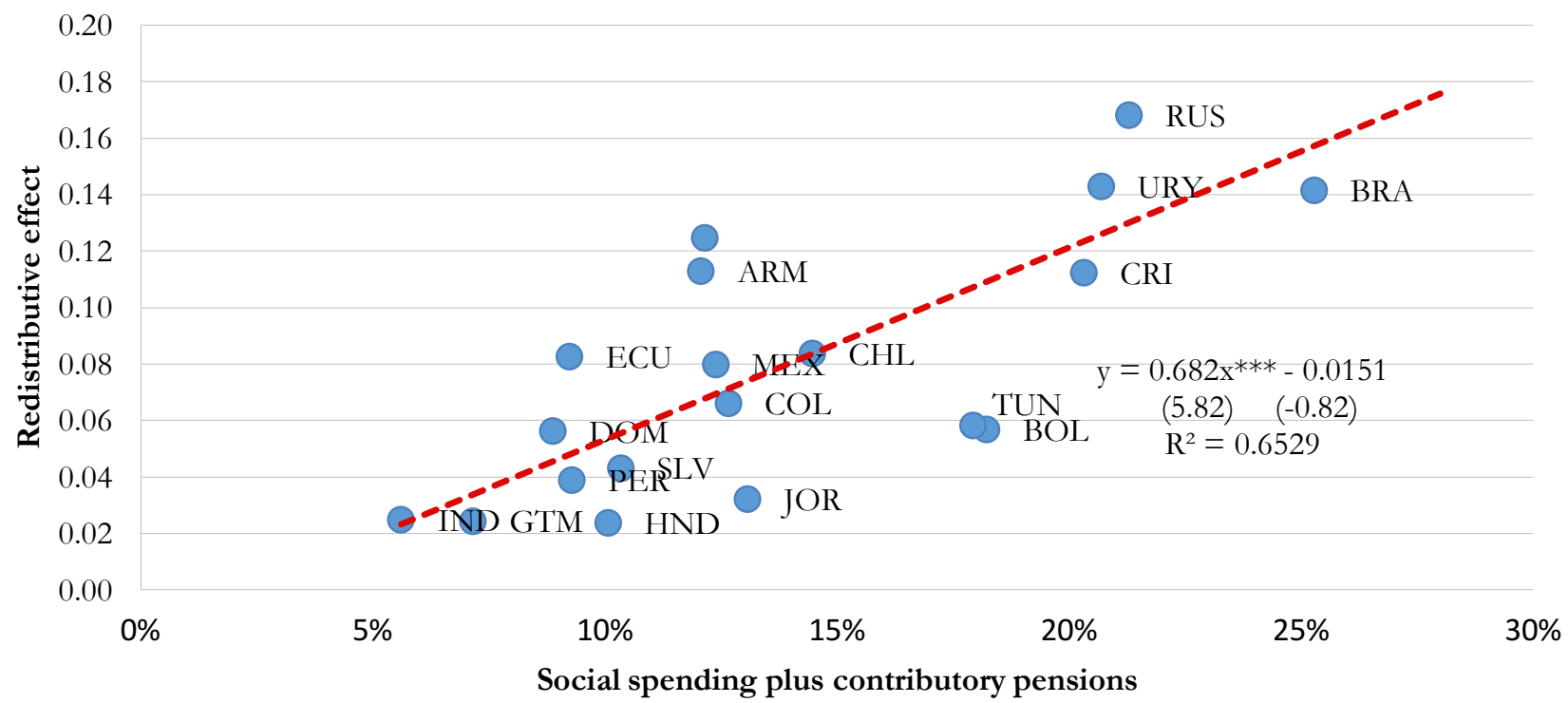

Source: CEQ Institute's Data Center on Fiscal Redistribution. Based on the following Master Workbooks of Results. Argentina: Rossignolo, 2017; Armenia: Younger and Khachatryan, 2014; Bolivia: Paz-Arauco et al., 2014b; Brazil: Higgins and Pereira, 2017; Chile: Martínez-Aguilar and Ortiz-Juarez, 2016; Colombia: Melendez and Martínez, 2015; Costa Rica: Sauma and Trejos, 2014b; Dominican Republic: Aristy-Escuder et al., 2016; Ecuador: Llerena et al., 2017; El Salvador: Beneke et al., 2014; Ethiopia: Hill et al., 2014; Georgia: Cancho and Bondarenko, 2015; Ghana: Younger et al., 2016; Guatemala: Cabrera and Morán, 2015; Honduras: Castañeda and Espino, 2015; Indonesia: Afkar, Jellema and Wai-Poi, 2015; Jordan: Abdel-Halim et al., 2016; Mexico: Scott, 2013; Peru: Jaramillo, 2015; Russia: Malytsin and Popova, 2016; South Africa: Inchauste et al., 2016; Sri Lanka: Arunatilake et al., 2016; Tanzania: Younger et al., 2016b; Tunisia: Jouni, et al., 2015; Uruguay: Bucheli et al., 2014.

Notes: The dotted line in red is the slope obtained from a simple regression with the redistributive effect as a dependent variable. Social Spending includes all direct transfers, education, health and other social spending. Redistributive effect is defined as the difference between Gini of market income plus contributory pensions and final income in Panel A and the difference between Gini of market income and final income in Panel B. Data shown here is administrative data as reported by the studies of each country and the numbers do not necessarily coincide with those of the databases from multilateral organizations. In parentheses are t statistics. ${ }^{*} \mathrm{p}<0.1,{ }^{* *} \mathrm{p}<0.05,{ }^{* * *} \mathrm{p}<0.01$.

The number of countries in panel B is smaller because it does not include the countries for which — for different reasonsthere is no additional scenario in which contributory pensions were considered a transfer, namely: Ethiopia, Georgia, Ghana, South Africa, Sri Lanka and Tanzania.

\section{ii Redistributive Effect: A Comparison with Advanced Countries}

How do these twenty-five countries compare with the fiscal redistribution that occurs in advanced countries? Although the methodology is somewhat different, one obvious comparator is the analysis produced by EUROMOD for the twenty-eight countries in the European Union. ${ }^{25}$ Given that EUROMOD covers only direct taxes, contributions to social security and direct transfers, the

25 The data for EU 28 is from EUROMOD statistics on Distribution and Decomposition of Disposable Income, accessed at http://www.iser.essex.ac.uk/euromod/statistics/ using EUROMOD version no. G3.0. 
comparison can be done for the redistributive effect from market to disposable income. A comparison is also made with the United States. ${ }^{26}$

There are three important differences between the advanced countries and the twenty-five ones analyzed here. First, market income inequality tends to be somewhat higher for the twenty-five countries. ${ }^{27}$ However, the difference is most striking when pensions are treated as transfers. The average market Gini coefficient for the twenty-five countries for the scenario in which pensions are treated as deferred income and the scenario in which they are considered transfers is 47.6 and 49.3 percent, respectively. In contrast, in the EU, the corresponding figures are 35.6 and 46.3 percent, respectively; and in the US, they are, 44.8-and 48.4, respectively. One important aspect to note, however, is that in the EU, pensions include both contributory and noncontributory social pensions while in the twenty-five countries and the US, the category of pensions includes only contributory pensions. In the scenario where we consider the pre-fisc income market income plus contributory pensions, the Gini for the pre-fisc income would be lower.

Second, as expected and shown in Figure 7, the redistributive effect is larger in the EU countries and, to a lesser extent, in the United States if pensions are considered a government transfer. In the twenty-five countries, whether pensions are treated as deferred income or a transfer makes a relatively small difference. This is not the case in the EU countries where the difference is huge. In the EU, the redistributive effect with contributory pensions as deferred income and contributory pensions as a transfer is 7.7 and 19.0 Gini points, respectively. In the United States, the numbers are less dramatically different: 7.2 and 11.2, respectively. In the twenty-five countries, the numbers are 2.7 and 3.9 Gini points, respectively. Clearly, the assumption made about how to treat incomes from pensions, again, makes a big difference.

${ }^{26}$ Higgins et al. (2015).

${ }^{27}$ South Africa pulls the average up but Indonesia pulls it down. 


\section{FIGURE 7: REDISTRIBUTIVE EFFECT: COMPARING DEVELOPING AND ADVANCED COUNTRIES (CHANGE IN GINI POINTS; CIRCA 2010)}

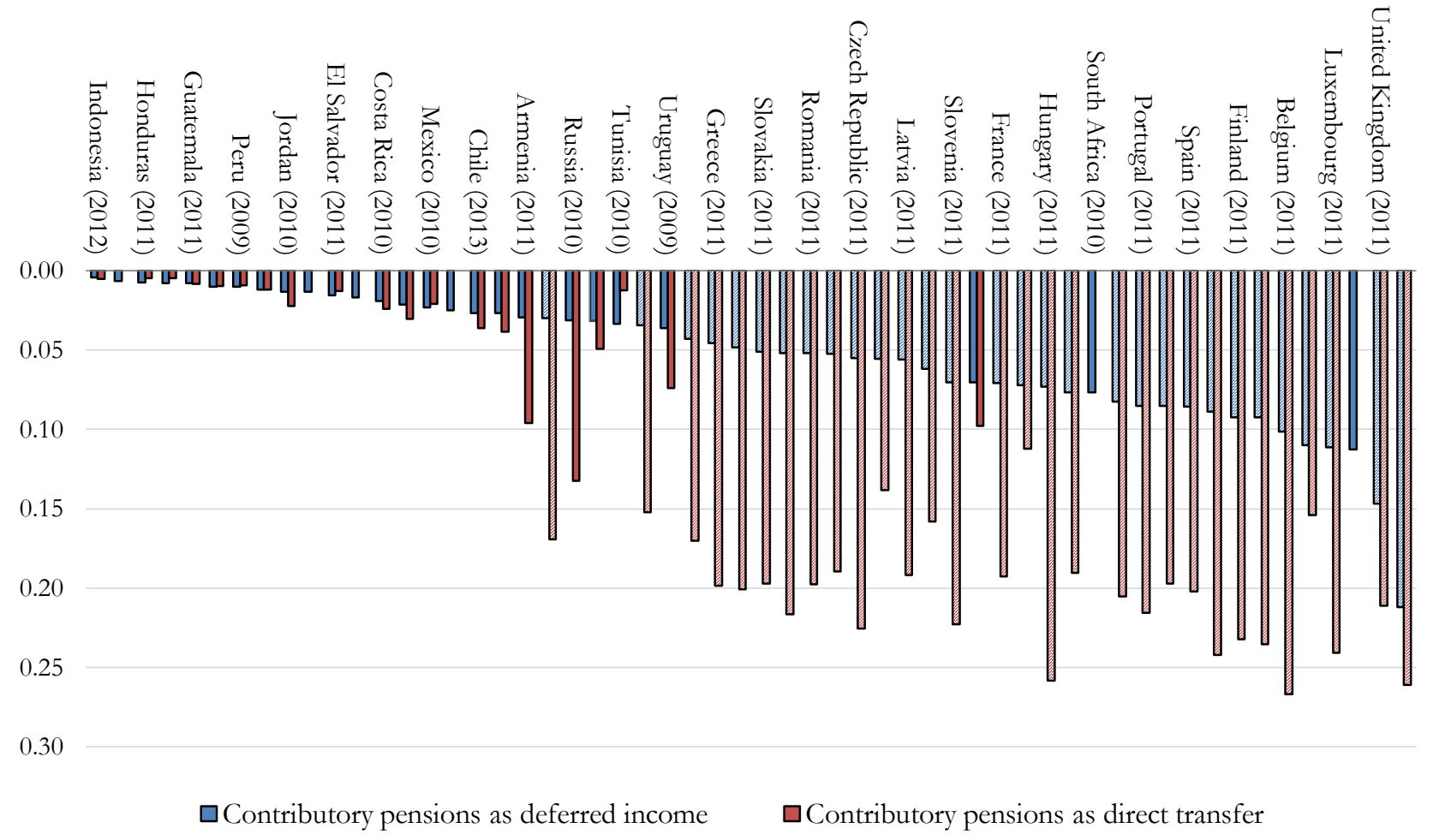

Source: CEQ Institute's Data Center on Fiscal Redistribution. Based on the following Master Workbooks of Results. Argentina: Rossignolo, 2017; Armenia: Younger and Khachatryan, 2014; Bolivia: Paz-Arauco et al., 2014b; Brazil: Higgins and Pereira, 2017; Chile: Martínez-Aguilar and Ortiz-Juarez, 2016; Colombia: Melendez and Martínez, 2015; Costa Rica: Sauma and Trejos, 2014b; Dominican Republic: Aristy-Escuder et al., 2016; Ecuador: Llerena et al., 2017; El Salvador: Beneke et al., 2014; Ethiopia: Hill et al., 2014; Georgia: Cancho and Bondarenko, 2015; Ghana: Younger et al., 2016; Guatemala: Cabrera and Morán, 2015; Honduras: Castañeda and Espino, 2015; Indonesia: Afkar, Jellema and Wai-Poi, 2015; Jordan: Abdel-Halim et al., 2016; Mexico: Scott, 2013; Peru: Jaramillo, 2015; Russia: Malytsin and Popova, 2016; South Africa: Inchauste et al., 2016; Sri Lanka: Arunatilake et al., 2016; Tanzania: Younger et al., 2016b; Tunisia: Jouni, et al., 2015; Uruguay: Bucheli et al., 2014.

For the European Union countries: EUROMOD statistics on Distribution and Decomposition of Disposable Income, accessed at http://www.iser.essex.ac.uk/euromod/statistics/ using EUROMOD version no. G3.0.

Notes: year of household survey in parenthesis. For definition of income concepts see the section on methodological highlights in text. Redistributive effect is defined as the difference between Gini of market income plus contributory pensions and disposable income with contributory pensions treated as deferred income and the difference between Gini of market income and disposable income with contributory pensions treated as transfers. The graph is ranked from the smallest to the largest by redistributive effect with contributory pensions treated as deferred income.

The number of countries in the scenario in which contributory pensions are treated as a transfer is smaller because it does not include the countries for which-for different reasons - there is no additional scenario in which contributory pensions were considered a transfer, namely: Ethiopia, Georgia, Ghana, South Africa, Sri Lanka and Tanzania.

While as seen in the previous section, in low and middle income countries pensions can sometimes be equalizing and unequalizing at other times, in no European country nor in the United States, contributory pensions are ever unequalizing. On the contrary, vis-à-vis market income without pensions, they 
exert a large equalizing force in the EU and less so in the US. Using data for 2011, for example, the difference between the market income Gini and the market income Gini plus contributory pensions is 10.7 percentage points in the EU and 3.6 in the United States.

FIGURE 8: MARGINAL CONTRIBUTION OF TAXES AND TRANSFERS (CIRCA 2010)

PANEL A: MARGINAL CONTRIBUTIONS OF NET DIRECT TAXES (CONTRIBUTORY PENSIONS AS DEFERRED INCOME)

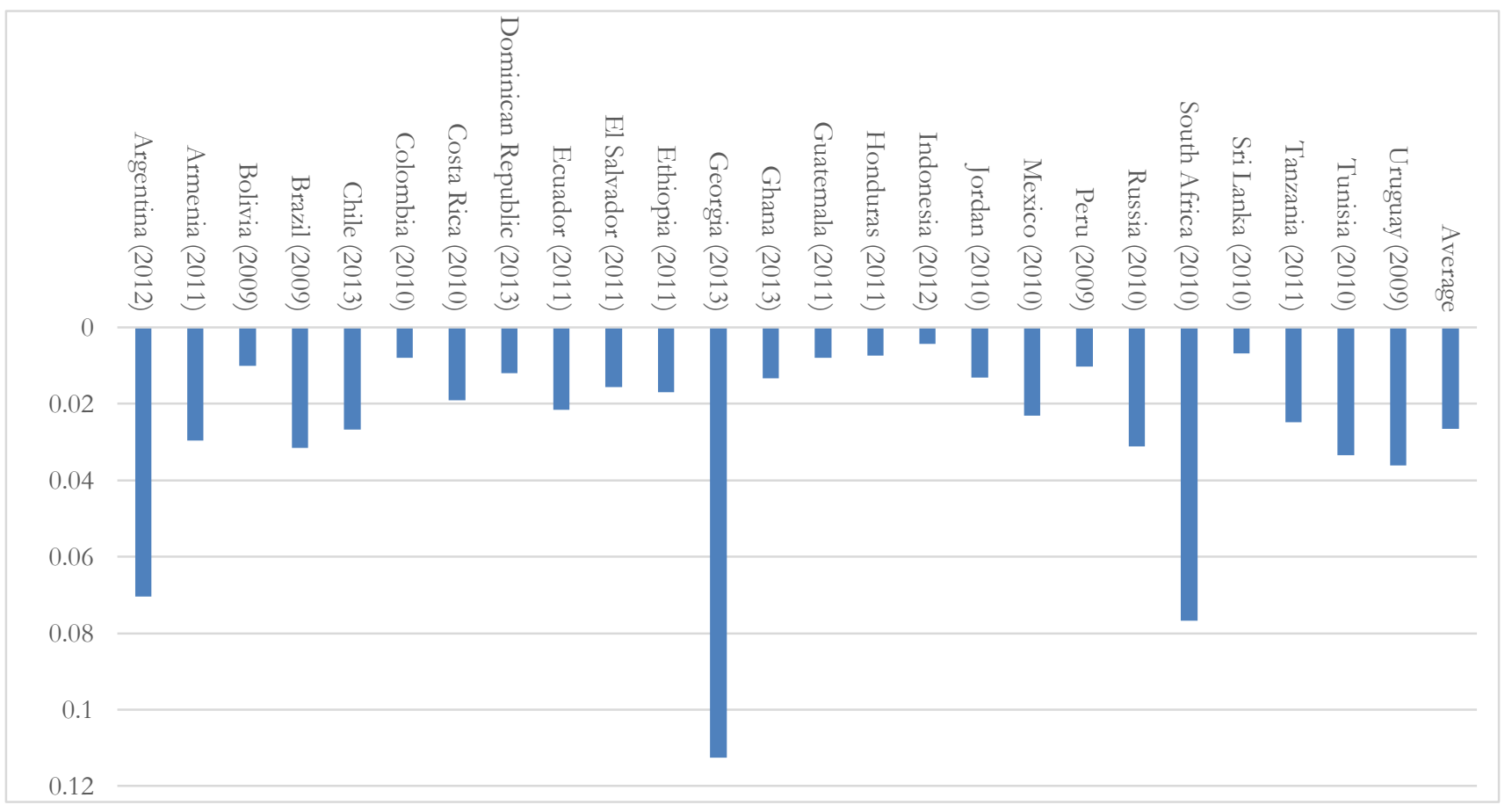


PANEL B: MARGINAL CONTRIBUTIONS OF NET INDIRECT TAXES (CONTRIBUTORY PENSIONS AS DEFERRED INCOME)

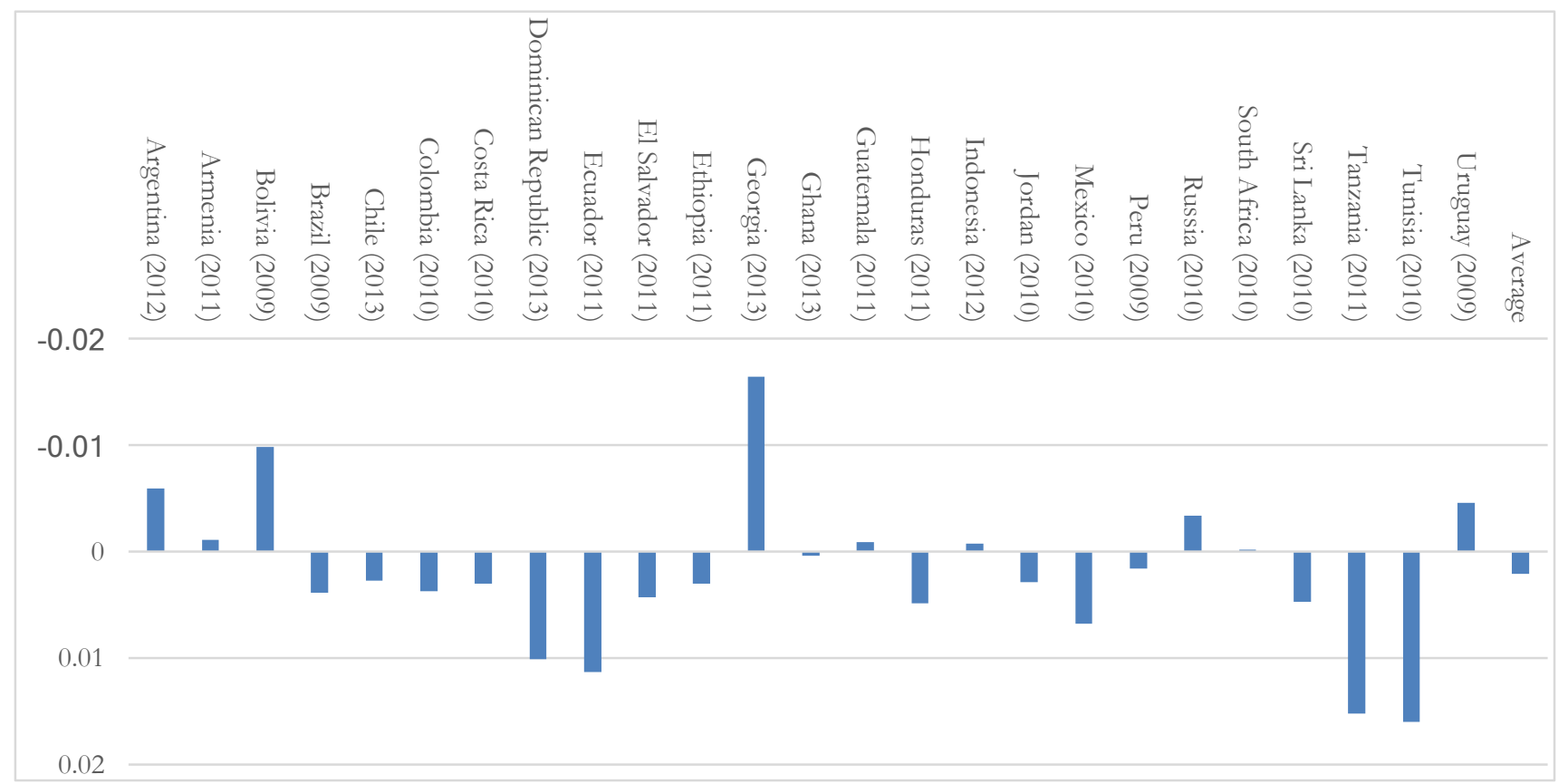

PANEL C: MARGINAL CONTRIBUTIONS OF IN-KIND TRANSFERS IN EDUCATION AND HEALTH (CONTRIBUTORY PENSIONS AS DEFERRED INCOME)

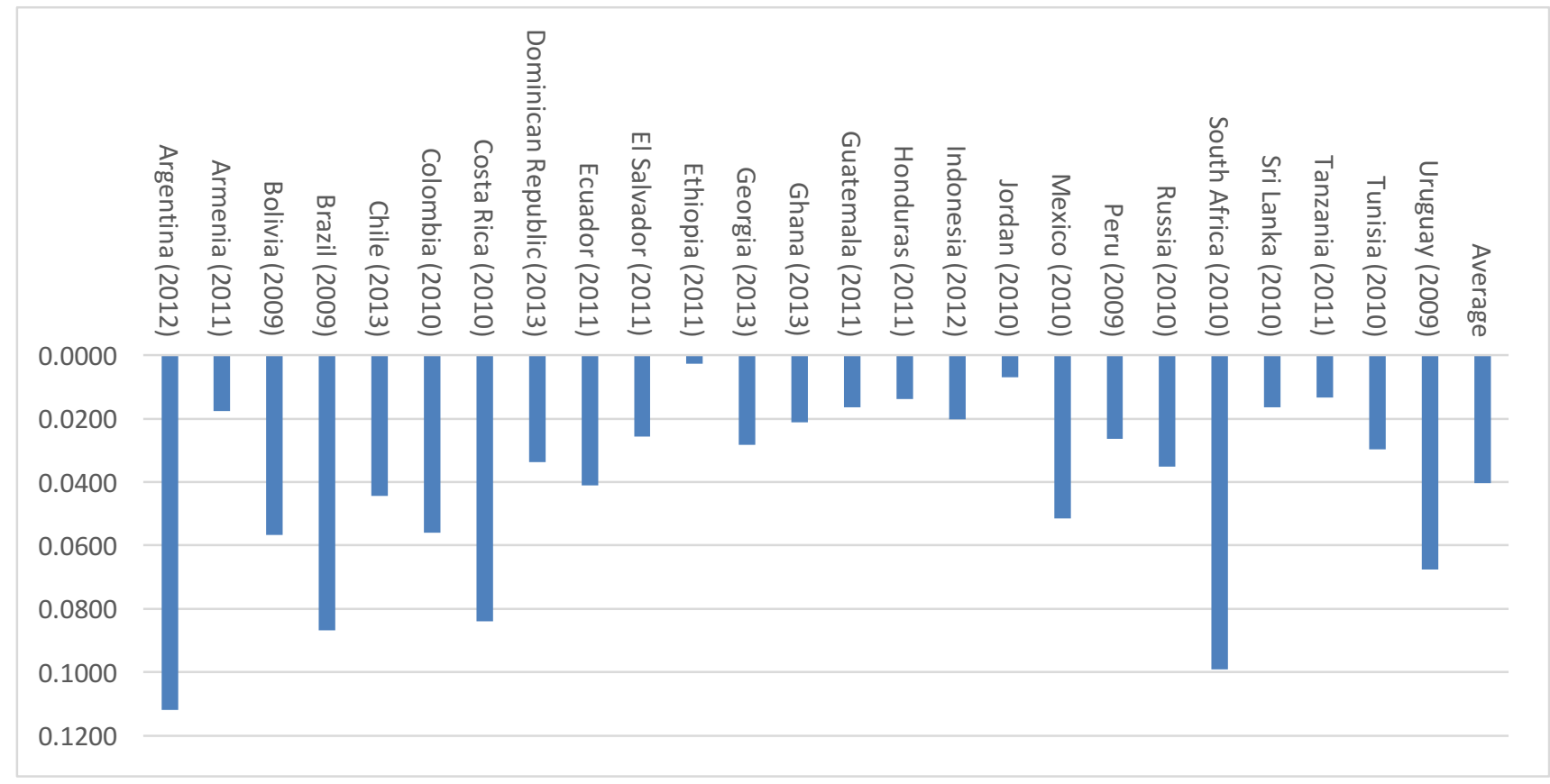

Source: CEQ Institute's Data Center on Fiscal Redistribution. Based on the following Master Workbooks of Results. Argentina: Rossignolo, 2017; Armenia: Younger and Khachatryan, 2014; Bolivia: Paz-Arauco et al., 2014b; Brazil: Higgins and Pereira, 2017; Chile: Martínez-Aguilar and Ortiz-Juarez, 2016; Colombia: Melendez and Martínez, 2015; Costa Rica: Sauma 
and Trejos, 2014b; Dominican Republic: Aristy-Escuder et al., 2016; Ecuador: Llerena et al., 2017; El Salvador: Beneke et al., 2014; Ethiopia: Hill et al., 2014; Georgia: Cancho and Bondarenko, 2015; Ghana: Younger et al., 2016; Guatemala: Cabrera and Morán, 2015; Honduras: Castañeda and Espino, 2015; Indonesia: Afkar, Jellema and Wai-Poi, 2015; Jordan: Abdel-Halim et al., 2016; Mexico: Scott, 2013; Peru: Jaramillo, 2015; Russia: Malytsin and Popova, 2016; South Africa: Inchauste et al., 2016; Sri Lanka: Arunatilake et al., 2016; Tanzania: Younger et al., 2016b; Tunisia: Jouni, et al., 2015; Uruguay: Bucheli et al., 2014.

Notes: The marginal contribution of net direct taxes is calculated as the difference between Gini of market income plus contributory pensions and disposable income (Panel A). The marginal contribution of net indirect taxes is calculated as the difference between Gini of disposable income and consumable income (Panel B). The marginal contribution of in-kind transfers is calculated as the difference between Gini of consumable income and final income (Panel C).

\section{FISCAL POLICY AND THE POOR}

The above discussion has concentrated on the impact of fiscal policy on inequality. As important is the impact of fiscal policy on poverty. In particular, because the results not necessarily go in the same direction: i.e., an inequality reducing fiscal system could be poverty increasing. The effect of fiscal policy on poverty can be measured using the typical indicators such as the headcount ratio for market income and income after taxes and transfers. Another measure that one can use to assess the impact of fiscal policy on the poor is the extent to which market income poor end up being net payers to the fiscal system in cash terms (leaving out in-kind services). A third measure is that of fiscal impoverishment (Higgins and Lustig, op. cit.): i.e., the extent to which fiscal policy makes the poor (nonpoor) poorer (poor).

When analyzing the impact of fiscal interventions on poverty, it is useful to distinguish between the net benefits in cash from the benefits received in the form of free government services in education and health. The cash component of fiscal policy impact is measured by comparing the indicators for consumable income with the same indicators using market income. The level of consumable income will tell whether the government has enabled an individual to be able to purchase private goods and services above his or her original market income. As shown in Figure 9 (panel A), using the \$2.50 (PPP 2005 a day) poverty line, ${ }^{28}$ fiscal policy reduces the headcount ratio for consumable income in most countries. ${ }^{29}$ However, there is a startling result. In the scenario in which pensions are considered deferred income, the consumable income headcount ratio for Armenia, Bolivia, Ethiopia, Ghana, Guatemala, Honduras, Sri Lanka, and Tanzania is higher than the headcount ratio for market income. This is a worrisome result. Poverty should not be higher as a result of fiscal policy. Note that this result occurs despite the fact that the net fiscal system (even without including in-kind transfers) reduces inequality. This emphasizes the fact that the impact of fiscal interventions on inequality and poverty should be studied separately.

\footnotetext{
${ }^{28}$ The $\$ 2.50$ a day poverty line is considered to be a reasonable international extreme poverty line for middle-income countries: for example, in the case of Latin America, this poverty line is close to the average of the local extreme poverty lines.

${ }^{29}$ Chile's result is particularly high because market income poverty is lower in Chile than in the other countries. Thus, a similar change in percentage points represents a large change when measured in percentage change as done in Figure 9 above.
} 
FIGURE 9: FISCAL POLICY AND POVERTY REDUCTION (CIRCA 2010): CHANGE IN HEADCOUNT RATIO FROM MARKET TO DISPOSABLE AND CONSUMABLE INCOME; IN \%

PANEL A: CONTRIBUTORY PENSIONS AS DEFERRED INCOME

(ranked by poverty reduction in \%; poverty line $\$ 2.52005 \mathrm{PPP} /$ day)

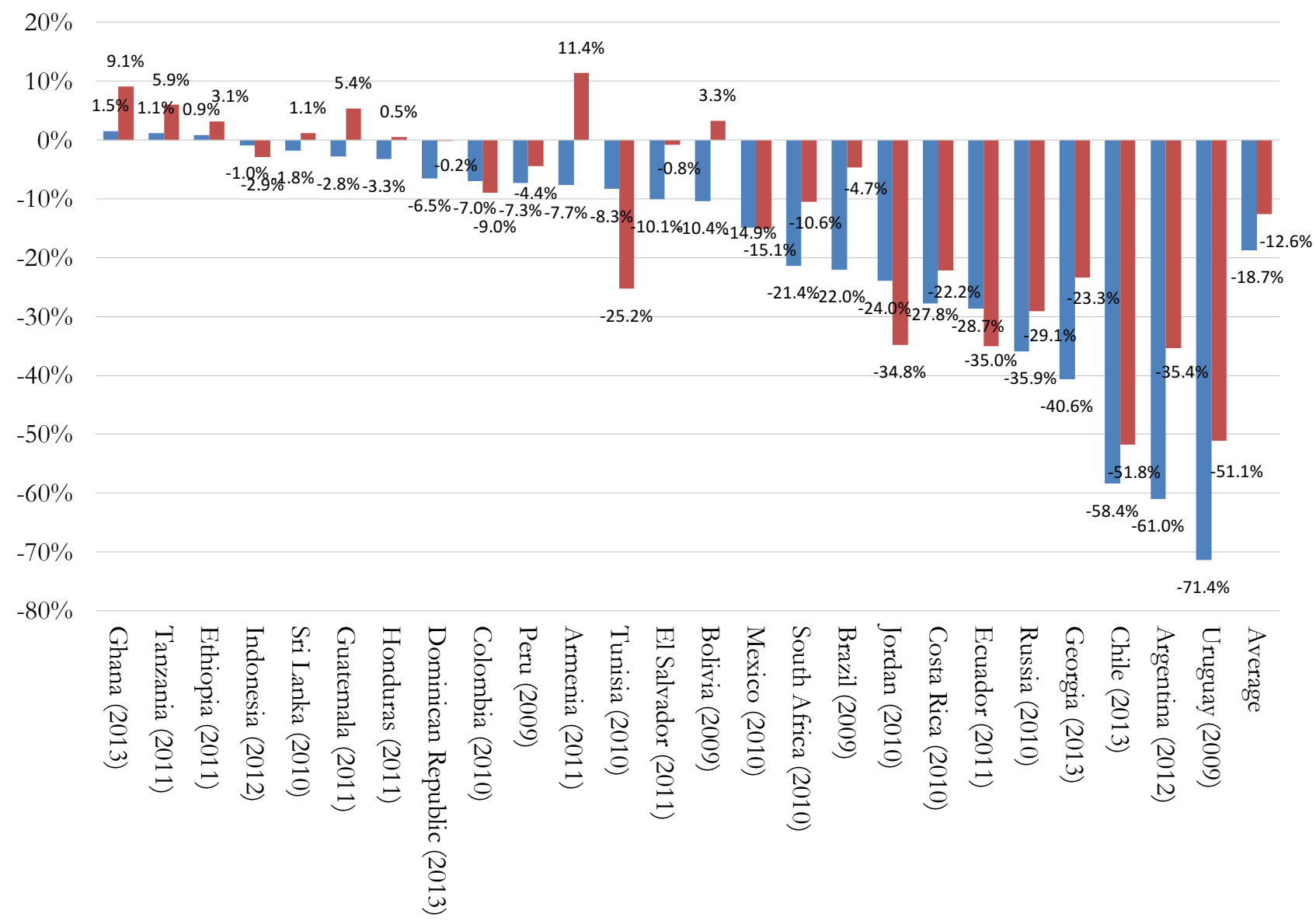

Market income plus pensions to disposable income $\quad$ Market income plus pensions to consumable income 


\section{PANEL B: CONTRIBUTORY PENSIONS AS TRANSFERS}

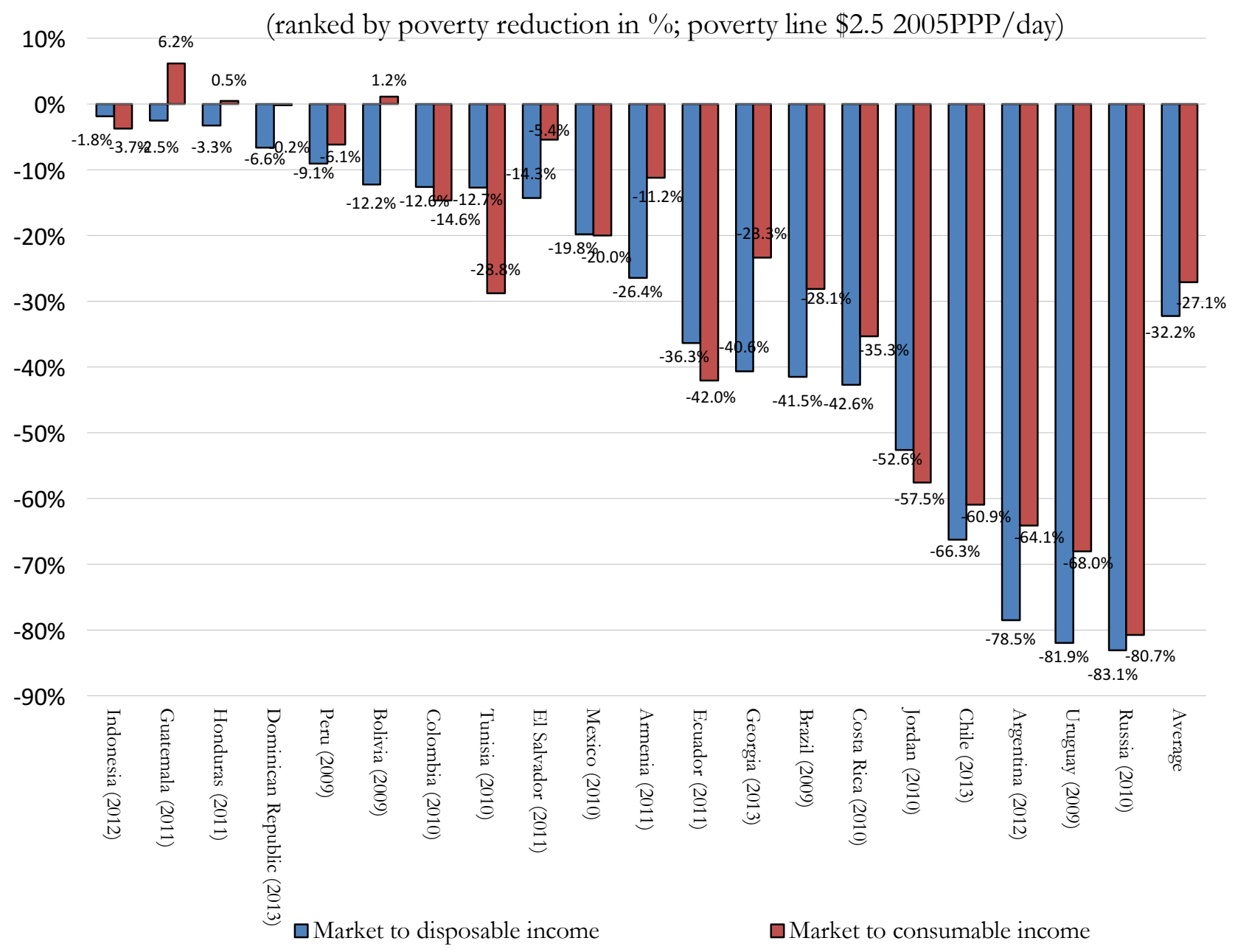

Source: CEQ Institute's Data Center on Fiscal Redistribution. Based on the following Master Workbooks of Results. Argentina: Rossignolo, 2017; Armenia: Younger and Khachatryan, 2014; Bolivia: Paz-Arauco et al., 2014b; Brazil: Higgins and Pereira, 2017; Chile: Martínez-Aguilar and Ortiz-Juarez, 2016; Colombia: Melendez and Martínez, 2015; Costa Rica: Sauma and Trejos, 2014b; Dominican Republic: Aristy-Escuder et al., 2016; Ecuador: Llerena et al., 2017; El Salvador: Beneke et al., 2014; Ethiopia: Hill et al., 2014; Georgia: Cancho and Bondarenko, 2015; Ghana: Younger et al., 2016; Guatemala: Cabrera and Morán, 2015; Honduras: Castañeda and Espino, 2015; Indonesia: Afkar, Jellema and Wai-Poi, 2015; Jordan: Abdel-Halim et al., 2016; Mexico: Scott, 2013; Peru: Jaramillo, 2015; Russia: Malytsin and Popova, 2016; South Africa: Inchauste et al., 2016; Sri Lanka: Arunatilake et al., 2016; Tanzania: Younger et al., 2016b; Tunisia: Jouni, et al., 2015; Uruguay: Bucheli et al., 2014.

Notes: Percentage of poverty reduction is defined as percentage change in headcount ratio from market income (or market income plus contributory pensions) to consumable income.

The number of countries in panel B is smaller because it does not include the countries for which-for different reasonsthere is no additional scenario in which contributory pensions were considered a transfer, namely: Ethiopia, Georgia, Ghana, South Africa, Sri Lanka and Tanzania.

In principle, it would be desirable for the poor-especially the extreme poor-to be net receivers of fiscal resources in cash so that poor individuals can buy/consume the minimum amounts of food and other essential goods imbedded in the selected poverty line. Figure 10 shows at which market income 
category, individuals_ - on average-become net payers to the fiscal system (again, this calculation only takes into account direct transfers in cash or near cash such as food). ${ }^{30}$ In Ghana and Tanzania net payers to the fiscal system begin in the income category $\$$ US0-\$US1.25/day in purchasing power parity known as ultra poor. In Guatemala, Ethiopia and Armenia net payers begin in the income group of extreme poor with \$US1.25-\$US2.50/day. In Sri Lanka, Peru, El Salvador, Dominican Republic, Honduras and Bolivia net payers to the fiscal system begin in the income category \$US2.50-\$US4/day in purchasing power parity. That is, in the group classified as moderately poor. In 11 countries; the net payers start in the group known as "vulnerable." In Indonesia, only the "rich" are net payers to the fiscal system (on average). ${ }^{31}$ If contributory pensions are considered a government transfer (not shown), net payers to fiscal system start in extreme poor income group in Guatemala and moderately poor group in Peru, Honduras, El Salvador, Dominican Republic, Bolivia and Armenia.

${ }^{30}$ Note that this graph presents a non-anonymous result: it looks at the extent to which the market income poor become net payers to the fiscal system on average. This information cannot be extrapolated from the typical poverty measures where winners and losers are not tracked.

31 These income categories are based on Lopez-Calva and Ortiz-Juárez (2014) and Ferreira et al. (2012). 


\section{FIGURE 10: NET PAYERS TO THE FISCAL SYSTEM BY INCOME GROUPS (CONTRIBUTORY PENSIONS AS DEFERRED INCOME)}

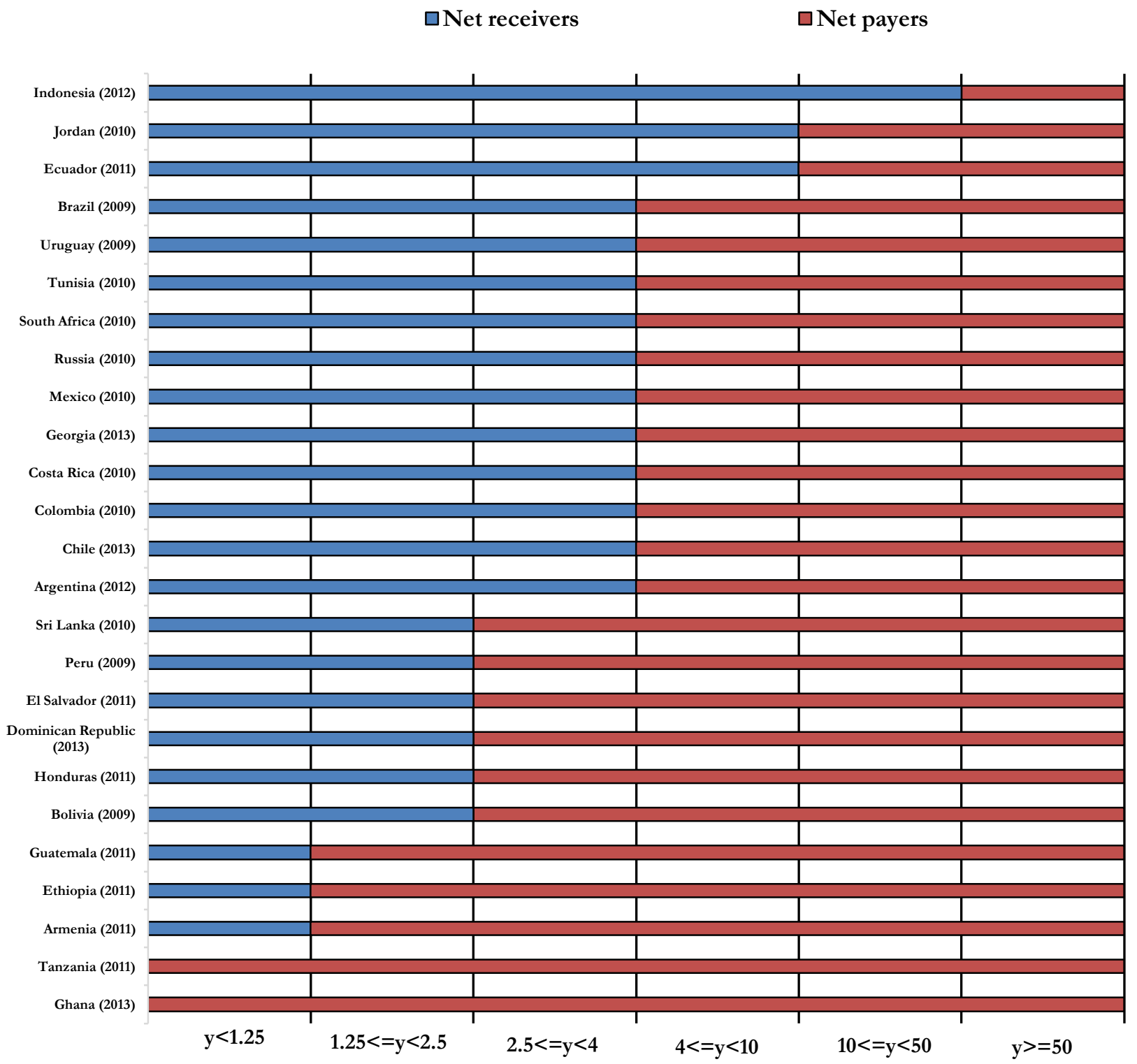

Source: CEQ Institute's Data Center on Fiscal Redistribution. Based on the following Master Workbooks of Results. Argentina: Rossignolo, 2017; Armenia: Younger and Khachatryan, 2014; Bolivia: Paz-Arauco et al., 2014b; Brazil: Higgins and Pereira, 2017; Chile: Martínez-Aguilar and Ortiz-Juarez, 2016; Colombia: Melendez and Martínez, 2015; Costa Rica: Sauma and Trejos, 2014b; Dominican Republic: Aristy-Escuder et al., 2016; Ecuador: Llerena et al., 2017; El Salvador: Beneke et al., 2014; Ethiopia: Hill et al., 2014; Georgia: Cancho and Bondarenko, 2015; Ghana: Younger et al., 2016; Guatemala: Cabrera and Morán, 2015; Honduras: Castañeda and Espino, 2015; Indonesia: Afkar, Jellema and Wai-Poi, 2015; Jordan: Abdel-Halim et al., 2016; Mexico: Scott, 2013; Peru: Jaramillo, 2015; Russia: Malytsin and Popova, 2016; South Africa: Inchauste et al., 2016; Sri Lanka: Arunatilake et al., 2016; Tanzania: Younger et al., 2016b; Tunisia: Jouni, et al., 2015; Uruguay: Bucheli et al., 2014. 
As can be seen in Table 1, the proportion of poor (nonpoor) people who were made poorer (poor) of the by fiscal policy as a share of the total population and, in particular, the consumable income poor is nontrivial. Moreover, this is so even though in the majority of countries shown on the table, the fiscal system is inequality and poverty reducing as revealed by the change in the headcount ratio and the Gini coefficient.

\section{TABLE 1: FISCAL IMPOVERISHMENT (CIRCA 2010): CONTRIBUTORY PENSIONS AS DEFERRED INCOME; IN \%}

\begin{tabular}{|c|c|c|c|c|c|c|c|}
\hline Country (survey year) & $\begin{array}{c}\text { Market } \\
\text { income plus } \\
\text { contributory } \\
\text { pensions } \\
\text { Poverty } \\
\text { headcount } \\
(\%)\end{array}$ & $\begin{array}{l}\text { Change in } \\
\text { poverty } \\
\text { headcount } \\
\text { (p.p.) }\end{array}$ & $\begin{array}{c}\text { Market } \\
\text { income plus } \\
\text { contributory } \\
\text { pensions } \\
\text { inequality } \\
\text { (Gini) }\end{array}$ & $\begin{array}{l}\text { Reynolds- } \\
\text { Smolensky }\end{array}$ & $\begin{array}{l}\text { Change in } \\
\text { inequality } \\
(\boldsymbol{\Delta} \text { Gini) }\end{array}$ & $\begin{array}{c}\text { Fiscally } \\
\text { impoverished } \\
\text { as } \% \text { of } \\
\text { population }\end{array}$ & $\begin{array}{c}\text { Fiscally } \\
\text { Impoverished } \\
\text { as } \% \text { of } \\
\text { consumable } \\
\text { income poor }\end{array}$ \\
\hline \multicolumn{8}{|c|}{$\begin{array}{l}\text { Panel A: Upper-middle income countries, using a poverty line of } \$ 2.5 \text { PPP } 2005 \\
\text { per day }\end{array}$} \\
\hline Brazil (2009) & 16.8 & -0.8 & 57.5 & 4.6 & -3.5 & 5.6 & 34.9 \\
\hline Chile (2013) & 2.8 & -1.4 & 49.4 & 3.2 & -3.0 & 0.3 & 19.2 \\
\hline Ecuador (2011) & 10.8 & -3.8 & 47.8 & 3.5 & -3.3 & 0.2 & 3.2 \\
\hline Mexico (2012) & 13.3 & -1.2 & 54.4 & 3.8 & -2.5 & 4.0 & 32.7 \\
\hline Peru (2011) & 13.8 & -0.2 & 45.9 & 0.9 & -0.8 & 3.2 & 23.8 \\
\hline Russia (2010) & 4.3 & -1.3 & 39.7 & 3.9 & -2.6 & 1.1 & 34.4 \\
\hline South Africa (2010) & 49.3 & -5.2 & 77.1 & 8.3 & -7.7 & 5.9 & 13.3 \\
\hline Tunisia (2010) & 7.8 & -0.1 & 44.7 & 8.0 & -6.9 & 3.0 & 38.5 \\
\hline \multicolumn{8}{|c|}{$\begin{array}{l}\text { Panel B: Lower-middle income countries, using a poverty line of } \\
\$ 1.252005 \text { PPP per day }\end{array}$} \\
\hline Armenia (2011) & 21.4 & -9.6 & 47.4 & 12.9 & -9.3 & 6.2 & 52.3 \\
\hline Bolivia (2009) & 10.9 & -0.5 & 50.3 & 0.6 & -0.3 & 6.6 & 63.2 \\
\hline Dominican Republic (2013) & 6.8 & -0.9 & 50.2 & 2.2 & -2.2 & 1.0 & 16.3 \\
\hline \multicolumn{8}{|l|}{ El Salvador (2011) } \\
\hline Ethiopia (2011) & 4.3 & -0.7 & 44.0 & 2.2 & -2.1 & 1.0 & 27.0 \\
\hline Ghana (2013) & 31.9 & 2.3 & 32.2 & 2.3 & -2.0 & 28.5 & 83.2 \\
\hline Guatemala (2010) & 6.0 & 0.7 & 43.7 & 1.6 & -1.4 & 5.1 & 76.6 \\
\hline Indonesia (2012) & 12.0 & -0.8 & 49.0 & 1.4 & -1.2 & 7.0 & 62.2 \\
\hline Sri Lanka (2010) & 12.0 & -1.5 & 39.8 & 1.1 & -0.8 & 4.1 & 39.2 \\
\hline Tanzania (2011) & 5.0 & -0.7 & 37.1 & 1.3 & -1.1 & 1.6 & 36.4 \\
\hline
\end{tabular}

Source: Higgins and Lustig (2016).

\section{EDUCATION AND HEALTH SPENDING ${ }^{32}$}

To what extent are the poor benefitting from government spending on education and health? The propoorness of public spending on education and health here is measured using concentration coefficients (also called quasi-Ginis). ${ }^{33}$ In keeping with conventions, spending is defined as regressive whenever the

\footnotetext{
32 Section based on Lustig (2015).

33 A concentration coefficient is calculated in a way analogous to the Gini coefficient. Let $p$ be the cumulative proportion of the total population when individuals are ordered in increasing income values using market income, and let $C(p)$ be the concentration curve, i.e., the cumulative proportion of total program benefits (of a particular program or aggregate category) received by the poorest $p$ percent of the population. Then, the concentration coefficient of that program or category is defined as $2 \int_{0}^{1}(p-\mathrm{C}(p)) d p$.
} 
concentration coefficient is higher than the Gini for market income. When this occurs, it means that the benefits from that spending as a share of market income tend to rise with market income. ${ }^{34}$ Spending is progressive whenever the concentration coefficient is lower than the Gini for market income. This means that the benefits from that spending as a share of market income tend to fall with market income. Within progressive spending, spending is neutral in absolute terms -- spending per capita is the same across the income distribution--whenever the concentration coefficient is equal to zero. Spending is defined as pro-poor whenever the concentration coefficient is not only lower than the Gini but also its value is negative. Pro-poor spending implies that the per capita government spending on the transfer tends to fall with market income. ${ }^{35}$ Any time spending is pro-poor or neutral in absolute terms, by definition it is progressive. The converse, of course, is not true. ${ }^{36}$ The taxonomy of transfers is synthesized in Diagram 2.

\footnotetext{
34 I say "tend" because for global regressivity/progressivity to occur it is not a necessary condition for the share of the benefit to rise/fall at each and every income level. When the latter occurs, the benefit is regressive/progressive everywhere. Whenever a benefit is everywhere regressive/progressive, it will be globally regressive/progressive, but the converse is not true.

${ }^{35}$ This case is also sometimes called progressive in absolute terms.

36 As mentioned above, care must be taken not to infer that any spending that is progressive (regressive) will automatically be equalizing (unequalizing).
} 


\title{
DIAGRAM 2: PROGRESSIVITY OF TRANSFERS
}

\author{
Progressivity of Transfers: A Diagrammatic Representation
}

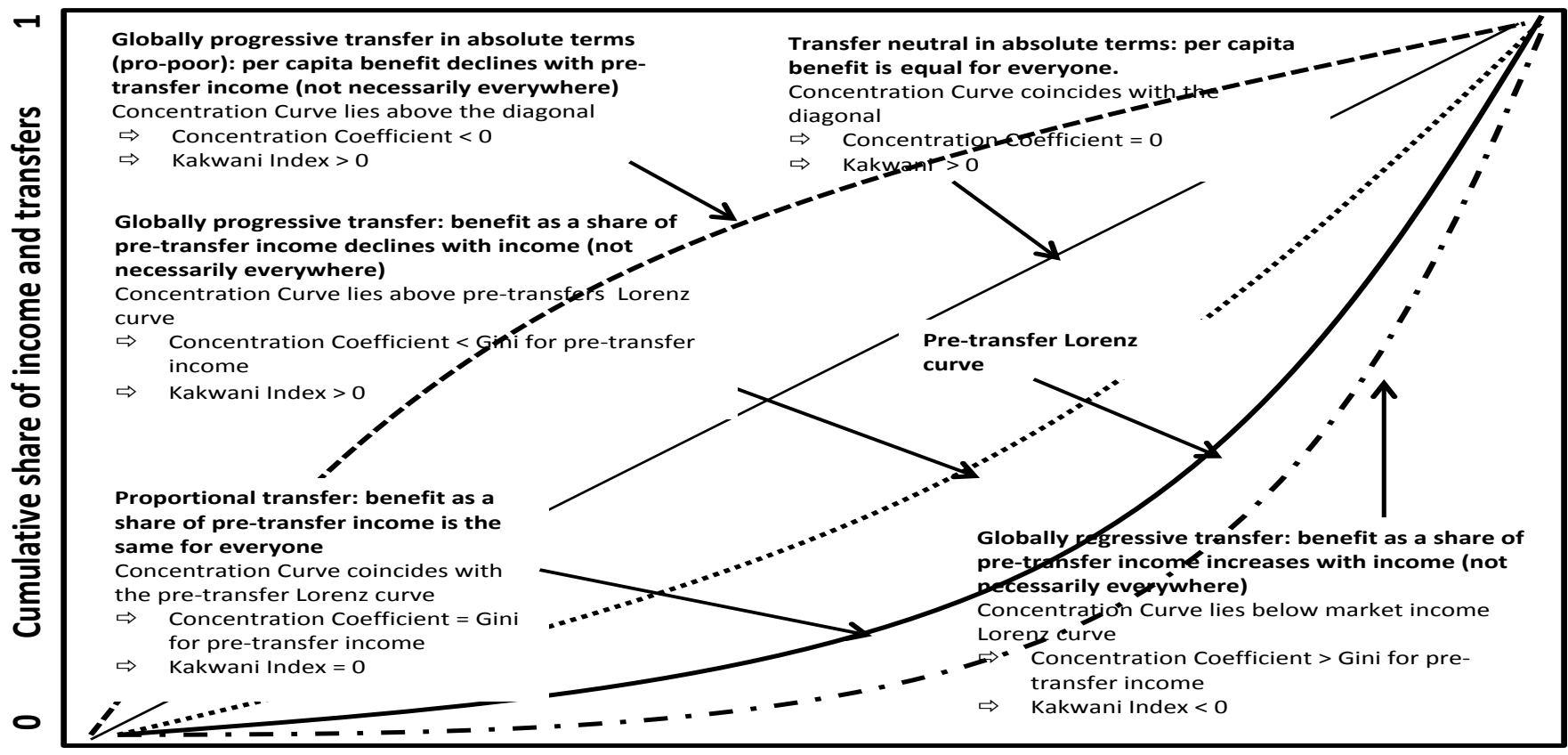

0 Cumulative share of population (ordered by market income)

Source: Lustig and Higgins (2018).

A clarification is in order. In the analysis presented here, households are ranked by per capita market income, and no adjustments are made to their size because of differences in the composition by age and gender. In some analyses, the pro-poorness of education spending, for example, is determined using children-not all members of the household--as the unit of analysis. Because poorer families have, on average, a larger number of children, the observation that concentration curves are pro-poor is a reflection of this fact. It doesn't mean that poorer families receive more resources per child.

Table 2 summarizes the results regarding the pro-poorness of government spending on education (total and by level) and health. Total spending on education is pro-poor (that is, per capita spending declines with income) in upper-middle-income and high-income countries except for South Africa and Tunisia, where it is (approximately) neutral in absolute terms. Total per capita spending on education tends to be the same (neutral in absolute terms) across different income groups in low-income and lower-middleincome countries, except for Armenia and El Salvador where it is pro-poor and Ethiopia where it is progressive only in relative terms. Pre-school tends to be pro-poor in all countries for which there is data except for Georgia. Primary school is pro-poor in all countries other than Ethiopia. For secondary school, spending is pro-poor in all upper-middle-income and high-income countries for which there is data except for Ecuador, where it is (approximately) neutral in absolute terms. Secondary school spending is neutral in most low-income and lower-middle-income countries other than Bolivia (pro- 
poor) and Ethiopia (progressive only in relative term). Government spending on tertiary education is regressive in Ethiopia, Tanzania, Ghana and Guatemala and progressive only in relative terms in various degrees in the rest.

Health spending is pro-poor (that is, per capita spending declines with income) in Georgia, Brazil, Dominican Republic, Ecuador, South Africa and all high-income economies other than Russia. In Armenia, Bolivia, Ghana, Honduras, Sri Lanka, Mexico and Tunisia, the per capita benefit is roughly the same across the income scale. In Ethiopia, Tanzania, El Salvador, Guatemala, Indonesia, Peru and Jordan, health spending per person is progressive in only relative terms.

While the results regarding the pro-poorness of spending on education and health are quite encouraging, a caveat is in order. Guaranteeing access and facilitating usage of public education and health services for the poor is not enough. As long as the quality of schooling and healthcare provided by the government is low, distortive patterns (e.g., mostly the middle-classes and the rich benefitting from free tertiary education), ${ }^{37}$ such as those observed in Brazil and South Africa, will be a major obstacle to the equalization of opportunities. However, with the existing information, one cannot disentangle to what extent the progressivity or pro-poorness of education and health spending is a result of differences in family composition (i.e., the poor have more children and, therefore, poor households receive higher benefits in the form of basic education transfers) or frequency of illness (i.e., the poor have worst health than the nonpoor) versus the "opting-out" of the middle-classes and the rich.

37 Among the reasons for this outcome is the fact that children of poor households tend to drop out of high school more and the rich children who receive enough quality (often private) education are better equipped to pass the entrance examination. 
TABLE 2: PROGRESSIVITY AND PRO-POORNESS OF EDUCATION AND HEALTH SPENDING. SUMMARY OF RESULTS

\begin{tabular}{|c|c|c|c|c|c|c|c|c|c|c|c|c|c|c|c|c|c|c|c|}
\hline & \multicolumn{3}{|c|}{$\begin{array}{c}\text { Education } \\
\text { Total }\end{array}$} & \multicolumn{3}{|c|}{ Pre-school } & \multicolumn{3}{|c|}{ Primary } & \multicolumn{3}{|c|}{ Secondary } & \multicolumn{4}{|c|}{ Tertiary } & \multicolumn{3}{|c|}{ Health } \\
\hline & $\mathrm{A}$ & $\mathrm{B}$ & $\mathrm{C}$ & A & $\mathrm{B}$ & $\mathrm{C}$ & $\mathrm{A}$ & $\mathrm{B}$ & $\mathrm{C}$ & A & B & $\mathrm{C}$ & A & B & $\mathrm{C}$ & $\mathrm{D}$ & A & $\mathrm{B}$ & $\mathrm{C}$ \\
\hline Argentina (2012) & + & & & + & & & -- & & & -- & & & & & + & & + & & \\
\hline Armenia (2011) & + & & & + & & & + & & & -- & & & & & + & & & + & \\
\hline Bolivia (2009) & & + & & + & & & + & & & + & & & & & + & & & + & \\
\hline Brazil (2009) & + & & & + & & & + & & & + & & & & & + & & + & & \\
\hline Chile (2013) & + & & & + & & & + & & & + & & & & & + & & + & & \\
\hline Colombia (2010) & - & & & + & & & + & & & + & & & & & + & & -- & & \\
\hline Costa Rica (2010) & - & & & + & & & + & & & + & & & & & + & & -- & & \\
\hline Dominican Republic (2013) & + & & & + & & & + & & & & & & & & + & & + & & \\
\hline Ecuador (2011) & + & & & -- & & & + & & & & & + & -- & & & & + & & \\
\hline El Salvador (2011) & + & & & + & & & + & & & & + & & & & + & & & & + \\
\hline Ethiopia (2011) & & & + & -- & & & & + & & & & + & & & & + & & & + \\
\hline Georgia (2013) & & + & & & + & & + & & & -- & & & & & + & & + & & \\
\hline Ghana (2013) & & & + & + & & & + & & & & & + & & & & + & & + & \\
\hline Guatemala (2011) & & + & & + & & & + & & & & + & & & & & + & & & + \\
\hline Honduras (2011) & & + & & + & & & + & & & & + & & & & + & & & + & \\
\hline Indonesia (2012) & & + & & & & & + & & & & + & & & & & + & & & + \\
\hline Jordan (2010) & + & & & + & & & + & & & + & & & & & + & & & & + \\
\hline Mexico (2010) & + & & & + & & & + & & & & & + & & & + & & & + & \\
\hline Peru (2009) & + & & & + & & & + & & & + & & & & & + & & & & + \\
\hline Russia (2010) & + & & & -- & & & -- & & & - & & & -- & & & & & + & \\
\hline South Africa (2010) & & + & & + & & & + & & & + & & & & & + & & + & & \\
\hline Sri Lanka (2010) & & + & & + & & & & -- & & & -- & & & & + & & & + & \\
\hline Tanzania (2011) & & & + & + & & & + & & & & & + & & & & + & & & + \\
\hline Tunisia (2010) & & + & & -- & & & -- & & & -- & & & & & + & & & + & \\
\hline Uruguay (2009) & + & & & + & & & + & & & + & & & & & + & & + & & \\
\hline
\end{tabular}




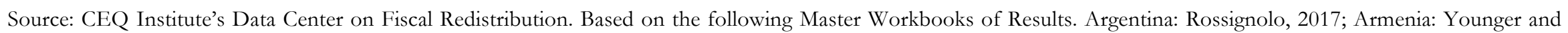

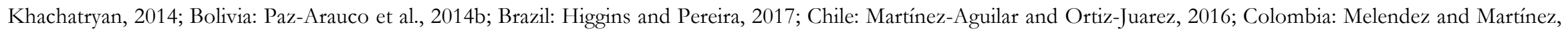
2015; Costa Rica: Sauma and Trejos, 2014b; Dominican Republic: Aristy-Escuder et al., 2016; Ecuador: Llerena et al., 2017; El Salvador: Beneke et al., 2014; Ethiopia: Hill et

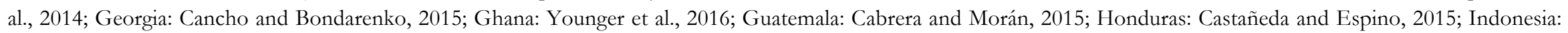

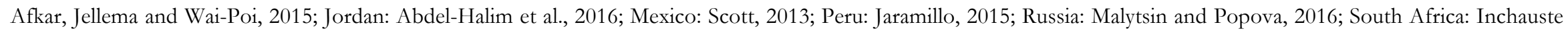
et al., 2016; Sri Lanka: Arunatilake et al., 2016; Tanzania: Younger et al., 2016b; Tunisia: Jouni, et al., 2015; Uruguay: Bucheli et al., 2014.

\section{Notes:}

$\mathrm{A}=$ Pro-poor, concentration coefficient is negative. $\mathrm{B}=$ Same per capita for all, concentration coefficient equals zero. $\mathrm{C}=$ Progressive, concentration coefficient positive

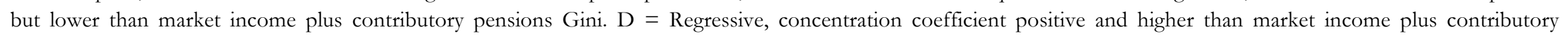
pensions Gini.

-- is not available

If the Concentration Coefficient is higher or equal to -0.5 but not higher than 0.5 , it was considered equal to 0 .

The scenario for South Africa assumed free basic services are direct transfers. 


\section{$7 \quad$ CONCLUSIONS}

In this paper, I examine the redistributive impact of fiscal policy in twenty-five low and middle income countries. In particular, I address the following questions: What is the impact of fiscal policy on inequality and poverty? What is the contribution of direct taxes and transfers, indirect taxes and subsidies, and spending on education and health to the overall reduction in inequality? How pro-poor is spending on education and health?

In order to analyze the impact of fiscal policy on income inequality it is useful to separate the "cash" portion of the system (direct and indirect taxes, direct transfers and indirect subsidies) from the "in kind" portion (the monetized value of the use of government education and health services). The results show that the reduction in inequality induced by the cash portion of the fiscal system is quite heterogeneous, with South Africa redistributing the most and Ethiopia the least. Redistributive success is broadly determined primarily by the amount of resources and their combined progressivity.

While the cash portion of the net fiscal system is always equalizing, the same cannot be said for poverty. In Armenia, Bolivia, Ethiopia, Ghana, Guatemala, Honduras, Tanzania and Sri Lanka the headcount ratio measured with the international extreme poverty line of US\$2.50 (PPP 2005 per day) is higher for consumable income than for market income. In these countries, fiscal policy increases poverty, meaning that a significant number of the market income poor (nonpoor) are made poorer (poor) by taxes and transfers (Higgins and Lustig, op. cit.). This startling result is primarily the consequence of high consumption taxes on basic goods.

Using as indicator the marginal contribution, direct transfers are always equalizing and direct taxes are equalizing except in Colombia, Ghana and Tanzania. The marginal contribution of direct transfers is higher than the marginal contribution of direct taxes in most countries except for Costa Rica, Jordan, Mexico and Peru. Indirect taxes are more often equalizing than not (which may come as a surprise). The effect of indirect taxes is unequalizing in Colombia, Georgia, Indonesia, Jordan, Russia but equalizing in Bolivia, Brazil, Chile, Costa Rica, Ecuador, El Salvador, Ghana, Mexico, Peru, South Africa, Tanzania, Sri Lanka, and Uruguay and neutral in Armenia. In Chile, indirect taxes are regressive, and yet equalizing. That is, in this country one finds the counter-intuitive result uncovered by Lambert (2001): a regressive tax is not always unequalizing because its effect depends on the distribution of all the other fiscal interventions combined. Indirect subsidies are equalizing except in Armenia, Ghana, and Tanzania, and education and health spending are always equalizing except health spending in Jordan. Measured with respect to market income, the marginal contribution of contributory social security old-age pensions is equalizing in Argentina, Armenia, Brazil, Chile, Costa Rica, Ecuador, Indonesia, Jordan, Russia and Uruguay, neutral in Dominican Republic and unequalizing in Bolivia, Colombia, El Salvador, Guatemala, Honduras, Mexico, Peru and Tunisia.

Turning now to the in-kind portion of the fiscal system, with the exception of health in Jordan, the marginal contribution of spending on education and health is equalizing and rather large. This result is not surprising given that the use of government services is monetized at a value equal to average government cost. While the results concerning the distribution of the benefits of in-kind services in education and health are encouraging from the equity point of view, it is important to note that they may 
be due to factors one would prefer to avoid. The more intensive use of services in education and health on the part of the poorer portions of the population, for example, may be caused by the fact that, in their quest for quality, the middle-classes (and, of course, the rich) chose to use private providers. This situation leaves the poor with access to second-rate services. In addition, if the middle-classes opt out of public services, they may be much more reluctant to pay the taxes needed to improve both the coverage and quality of services than they would be if services were used universally.

There are a few lessons that emerge from the analysis. Let's start with those pertaining to the diagnostic of fiscal redistribution. First, the fact that specific fiscal interventions can have countervailing effects underscores the importance of taking a coordinated view of both taxation and spending rather than pursuing a piecemeal analysis. Efficient regressive taxes (such as the VAT) when combined with generous well-targeted transfers can result in a net fiscal system that is equalizing. Even more, because a net fiscal system with a regressive tax could be more equalizing than without it (Lambert's conundrum), policy recommendations - such as eliminating the regressive tax--based on a piecemeal analysis could be flatly wrong. Second, to assess the impact of the fiscal system on people's standard of living, it is crucial to measure the effect of taxation and spending not only on inequality but also on poverty: the net fiscal system can be equalizing but poverty-increasing.

Regarding policy prescriptions, one fundamental lesson emerges: governments should design their tax and transfers system so that the after taxes and transfers incomes (or consumption) of the poor are not lower than their incomes (or consumption) before fiscal interventions. Leaving out in-kind transfers, the so-called cash portion of the fiscal system should not impoverish the poor (or make the non-poor poor). The results indicate that the ultra poor in Ghana and Tanzania, the extreme poor in Armenia, Ethiopia and Guatemala and the moderate poor in Sri Lanka, Peru, El Salvador, Dominican Republic, Honduras and Bolivia are net payers into the fiscal system. In the case of Brazil, the cause is the high consumption taxes paid on staple goods. In the case of Peru, cash transfers are too small to compensate for what the poor pay in taxes. Furthermore, as shown in Higgins and Lustig (op. cit.), fiscal impoverishment can be quite pervasive and, in low-income countries, larger in magnitude than fiscal gains to the poor.

The current policy discussion (and the literature) focuses primarily on the power of fiscal policy to reduce inequality and much less (and often not at all) on the impact of fiscal policy on the standard of living of the poor. If the policy community is seriously committed to eradicating income poverty, governments will need to explore ways to redesign taxation and transfers so that the poor do not end up as net payers. This could become an overriding principle in the design of fiscal systems that could be explicitly added to the frameworks proposed by Atkinson (2015) and Stiglitz (2012) to build more equitable societies. 


\section{REFERENCES}

Abdel-Halim, M., Y. Mansur, U. Serajuddin, and P. Verme. 2016. CEQ Master Workbook: Jordan. CEQ Data Center on Fiscal Redistribution (CEQ Institute, Tulane University and the World Bank), version: March 8.

Afkar, R., J. Jellema, and M. Wai Poi. 2015. CEQ Master Workbook: Indonesia. CEQ Data Center on Fiscal Redistribution (CEQ Institute, Tulane University and the World Bank), version February 26.

Alam, S. A., G. Inchauste, and U. Serajuddin. 2017. "The Distributional Impact of Fiscal Policy in Jordan." In The Distributional Impact of Fiscal Policy: Experience from Developing Countries, edited by Gabriela Inchauste and Nora Lustig. Washington, D.C.: World Bank.

Aristy-Escuder, J., M. Cabrera, B. Moreno-Dodson, and M. E. Sánchez-Martín. 2016. CEQ Master Workbook: Dominican Republic. CEQ Data Center on Fiscal Redistribution (CEQ Institute, Tulane University and the World Bank), version: August 4.

--------. 2018. "Fiscal Policy and Redistribution in the Dominican Republic," Chapter 14 in Commitment to Equity Handbook. Estimating the Impact of Fiscal Policy on Inequality and Poverty, edited by Nora Lustig (Brookings Institution Press and CEQ Institute, Tulane University). Advance online version available at

http://www.commitmentoequity.org/publications/handbook.php.

Arunatilake, N., G. Inchauste, and N. Lustig. 2017. "The Incidence of Taxes and Spending in Sri Lanka." In The Distributional Impact of Fiscal Policy: Experience from Developing Countries, edited by Gabriela Inchauste and Nora Lustig. Washington, D.C.: World Bank.

Arunatilake, N., C. Gomez, N. Perera and K. Attygalle. 2016. CEQ Master Workbook: Sri Lanka. CEQ Data Center on Fiscal Redistribution (CEQ Institute, Tulane University and the World Bank), version: March 10.

Atkinson, Anthony B. 2015. Inequality. What Can Be Done? Harvard University Press, Cambridge, Massachusetts.

Beneke, M., N. Lustig, and J. A. Oliva. 2014. CEQ Master Workbook: El Salvador. CEQ Data Center on Fiscal Redistribution (CEQ Institute, Tulane University and the Inter-American Development Bank), version: June 26.

------2018. "The Impact of Taxes and Social Spending on Inequality and Poverty in El Salvador," Chapter 15 in Commitment to Equity Handbook. Estimating the Impact of Fiscal Policy on Inequality and Poverty, edited by Nora Lustig (Brookings Institution Press and CEQ Institute, Tulane University). Advance online version available at 


\section{http://www.commitmentoequity.org/publications/handbook.php.}

Breceda, K, J. Rigolini and J. Saavedra. 2008. "Latin America and the Social Contract: Patterns of Social Spending and Taxation." Policy Research Working Paper 4604. World Bank Latin American and Caribbean Region Poverty Department Poverty Reduction and Economic Management Division. Washington DC: World Bank. Available online http://go.worldbank.org/BWBRP91A50

Bucheli, M., N. Lustig, M. Rossi, and F. Amábile. 2014. "Social Spending, Taxes and Income Redistribution in Uruguay." In The Redistributive Impact of Taxes and Social Spending in Latin America edited by Nora Lustig, Carola Pessino and John Scott. Special Issue, Public Finance Review 42, no. 3.

------ 2014. CEQ Master Workbook: Uruguay. CEQ Data Center on Fiscal Redistribution (CEQ Institute, Tulane University), version: August 18.

Cabrera, M., N. Lustig, and H. Moran. 2015. "Fiscal Policy, Inequality and the Ethnic Divide in Guatemala." World Development 76: 263-279.

Cabrera, Maynor and Hilcias E. Moran. 2015. CEQ Master Workbook: Guatemala. CEQ Data Center on Fiscal Redistribution (CEQ Institute, Tulane University, Instituto Centroamericano de Estudios Fiscales (Icefi) and International Fund for Agricultural Development (IFAD)), version May 6.

Cancho, C., and E. Bondarenko. 2017. "The Distributional Impact of Fiscal Policy in Georgia.” In The Distributional Impact of Fiscal Policy: Experience from Developing Countries, edited by Gabriela Inchauste and Nora Lustig. Washington, D.C.: World Bank.

. 2015. CEQ Master Workbook: Georgia. CEQ Data Center on Fiscal Redistribution (CEQ Institute, Tulane University and the World Bank), version: December 31.

Castañeda, R., and I. Espino. 2015. CEQ Master Workbook: Honduras. CEQ Data Center on Fiscal Redistribution (CEQ Institute, Tulane University, Instituto Centroamericano de Estudios Fiscales (Icefi) and International Fund for Agricultural Development (IFAD)), version: August 18.

Duclos, J. and A. Araar. 2006. Poverty and Equity: Measurement, Policy and Estimation with DAD (Vol. 2). Springer.

Enami, A., N. Lustig, and R. Aranda. 2018. "Analytical Foundations: Measuring the Redistributive Impact of Taxes and Transfers," Chapter 2 in Commitment to Equity Handbook. Estimating the Impact of Fiscal Policy on Inequality and Poverty, edited by Nora Lustig (Brookings Institution Press and CEQ Institute, Tulane University). Advance online version available at 


\section{http://www.commitmentoequity.org/publications/handbook.php.}

EUROMOD statistics on Distribution and Decomposition of Disposable Income, accessed at http://www.iser.essex.ac.uk/euromod/statistics/ using EUROMOD version no. G3.0.

Ferreira, F. H. G., J. Messina, J. Rigolini, L.F. Lopez-Calva, M. A. Lugo, and R. Vakis. 2012. "Economic mobility and the Rise of the Latin American Iddle Class. Washington, DC: The World Bank.

Förster, M. and P. Whiteford. 2009. "How much Redistribution do Welfare States Achieve? The Role of Cash Transfers and Household Taxes," CESifo DICE Report, Ifo Institute for Economic Research at the University of Munich, vol. 7(3), pages 34-41, October.

Goñi, E., J. H. López, and L. Servén. 2011. "Fiscal Redistribution and Income Inequality in Latin America." World Development 39(9): 1558-1569.

Higgins, S. and C. Pereira. 2014. "The Effects of Brazil's Taxation and Social Spending on the Distribution of Household Income." In The Redistributive Impact of Taxes and Social Spending in Latin America edited by Nora Lustig, Carola Pessino and John Scott. Special Issue, Public Finance Review 42, no. 3.

2017. CEQ Master Workbook: Brazil, CEQ Data Center on Fiscal Redistribution (CEQ Institute, Tulane University), version: April 19.

Higgins, S. and N. Lustig. 2016. "Can a Poverty-Reducing and Progressive Tax and Transfer System Hurt the Poor?" Journal of Development Economics, DOI: 10.1016/j.jdeveco.2016.04.001.

Higgins, S., N. Lustig, W. Ruble and T. Smeeding. 2016. * "Comparing the Incidence of Taxes and Social Spending in Brazil and the United States." Review of Income and Wealth, 62, S22-46.

Hill, R., G. Inchauste, N. Lustig, E. Tsehaye and T. Woldehanna. 2016. "A Fiscal Incidence Analysis for Ethiopia." In The Distributional Impact of Fiscal Policy: Experience from Developing Countries, edited by Gabriela Inchauste and Nora Lustig. Washington, D.C.: World Bank, 2017.

Hill, R., E. Tsehaye and T. Woldehanna. 2014. CEQ Master Workbook: Ethiopia. CEQ Data Center on Fiscal Redistribution (CEQ Institute, Tulane University and the World Bank), version: September 28.

Icefi. 2017. "Incidencia de la politica fiscal en el ambito rural de Centro America: el caso de Honduras," CEQ Working Paper 51 (CEQ Institute, Tulane University, IFAD and Instituto Centroamericano de Estudios Fiscales). 
Immervoll, H., Horacio L., J. R. Nogueira, C. O’Donoghue, and R. Bezerra de Siqueira. 2009. "The Impact of Brazil's Tax-Benefit System on Inequality and Poverty." In Poverty, Inequality, and Policy in Latin America, edited by Stephan Klasen and Felicitas Nowak Lehmann, 271-302. Cambridge, M.A.: MIT Press.

--- and L. Richardson. 2011. "Redistribution Policy and Inequality Reduction in OECD Countries: What Has Changed in Two Decades?” IZA Discussion Paper No. 6030, October.

--- and C. O’Donoghue. 2001. "Imputation of Gross Amounts from Net Incomes in Household Surveys: An Application using EUROMOD”, EUROMOD Working Paper EM1/01, University of Essex, https://www.iser.essex.ac.uk/research/publications/workingpapers/euromod/em1-01.pdf.

Inchauste, G. and N. Lustig, editors. 2017. The Distributional Impact of Fiscal Policy. Evidence from Developing Countries. (Washington: World Bank)

Inchauste, G., N. Lustig, M. Maboshe, C. Purfield, I. Woolard, and P. Zikhali. 2016. CEQ Master Workbook: South Africa." CEQ Data Center on Fiscal Redistribution (CEQ Institute, Tulane University and the World Bank), version March 6, 2016.

2017. "The Distributional Impact of Fiscal Policy in South Africa," in The Distributional Impact of Fiscal Policy: Experience from Developing Countries, edited by Gabriela Inchauste and Nora Lustig. (Washington: World Bank).

Jaramillo, M. 2014. "The Incidence of Social Spending and Taxes in Peru." In The Redistributive Impact of Taxes and Social Spending in Latin America edited by Nora Lustig, Carola Pessino and John Scott. Special Issue, Public Finance Review 42, no. 3.

2015. CEQ Master Workbook: Peru. CEQ Data Center on Fiscal Redistribution (CEQ Institute, Tulane University), version: August 7.

Jellema, J., M. Wai Poi and R. Afkar. 2017. "The Distributional Impact of Fiscal Policy in Indonesia." In The Distributional Impact of Fiscal Policy: Experience from Developing Countries, edited by Gabriela Inchauste and Nora Lustig. Washington, D.C.: World Bank.

Kakwani, N. C. 1977. "Measurement of tax progressivity: an international comparison." The Economic Journal: 71-80.

Lambert, P. 2001. The Distribution and Redistribution of Income. Third Edition. Manchester University Press.

Lindert, K., E. Skoufias, and J. Shapiro. 2006. "Redistributing Income to the Poor and Rich: Public Transfers in Latin America and the Caribbean." Social Protection Discussion Paper 0605. Washington, D.C.: The World Bank. 
Llerena Pinto, F. P., M. C. Llerena Pinto, R. C. Saá Daza, and M. A. Llerena Pinto. 2015. "Social Spending, Taxes and Income Redistribution in Ecuador." CEQ Working Paper No. 28, Center for Inter-American Policy and Research and Department of Economics, Tulane University and Inter-American Dialogue.

------- 2017. CEQ Master Workbook: Ecuador. CEQ Data Center on Fiscal Redistribution (CEQ Institute, Tulane University), version: January 5.

Lopez-Calva, L. F., and E. Ortiz-Juárez. 2014. "A Vulnerability Approach to the Definition of the Middle Class.” Journal of Economic Inequality, 12(1): 23-47.

Lopez-Calva, L. F., N. Lustig, M. Matytsin and D. Popova. 2017. "Who Benefits from Fiscal Redistribution in Russia?" In The Distributional Impact of Fiscal Policy: Experience from Developing Countries, edited by Gabriela Inchauste and Nora Lustig. Washington, D.C.: World Bank.

Lustig, Nora, editor. 2018. Commitment to Equity Handbook. Estimating the Impact of Fiscal Policy on Inequality and Poverty (Brookings Institution Press and CEQ Institute, Tulane University). Advance online version available at http://www.commitmentoequity.org/publications/handbook.php.

. 2015. "The Redistributive Impact of Government Spending on Education and Health: Evidence from 13 Developing Countries in the Commitment to Equity Project," in Inequality and Fiscal Policy, edited by Sanjeev Gupta, Michael Keen, Benedict J. Clements and Ruud A. de Mooij (Washington: International Monetary Fund).

Lustig, Nora and Sean Higgins. 2013. "Commitment to Equity Assessment (CEQ): Estimating the Incidence of Social Spending, Subsidies and Taxes. Handbook," CEQ Working Paper 1 (Center for Inter-American Policy and Research, Department of Economics, Tulane University, and Inter-American Dialogue), September. [Version replaced by Lustig, editor, 2018]

. 2018. "The CEQ Assessment: Measuring the Impact of Fiscal Policy on Inequality and Poverty," Chapter 1 in Commitment to Equity Handbook. Estimating the Impact of Fiscal Policy on Inequality and Poverty, edited by Nora Lustig (Brookings Institution Press and CEQ Institute, Tulane University). Advance online version available at http://www.commitmentoequity.org/publications/handbook.php.

Malytsin, M. and D. Popova. 2016. CEQ Master Workbook: Russia. CEQ Institute, Tulane University and the World Bank, version: March 17. 
Martinez-Aguilar, S. and E. Ortiz-Juarez. 2016. CEQ Master Workbook: Chile. CEQ Data Center on Fiscal Redistribution (CEQ Institute, Tulane University and the World Bank), version October 7.

Martinez-Aguilar, S., A. Fuchs, E. Ortiz-Juarez, and G. del Carmen. 2018. "The Impact of Fiscal Policy on Inequality and Poverty in Chile," Chapter 13 in Commitment to Equity Handbook. Estimating the Impact of Fiscal Policy on Inequality and Poverty, edited by Nora Lustig (Brookings Institution Press and CEQ Institute, Tulane University). Advance online version available at http://www.commitmentoequity.org/publications/handbook.php.

Martínez-Vazquez, J. 2008. "The Impact of Budgets on the Poor: Tax and Expenditure Benefit Incidence Analysis." In B. Moreno-Dodson \& W. Quentin (Eds.), Public Finance for Poverty Reduction: Concepts and Case Studies from Africa and Latin America. World Bank, Washington, DC.

Melendez, M. and V. Martínez. 2015. CEQ Master Workbook: Colombia. CEQ Data Center on Fiscal Redistribution (CEQ Institute, Tulane University and Inter-American Development Bank), version: December 17.

Musgrave, R. 1959. The Theory of Public Finance. McGraw-Hill, New York.

OECD. 2011. "Changes in Redistribution in OECD Countries Over Two Decades." In Divided We Stand. Why Inequality Keeps Rising. OECD Publishing. http://dx.doi.org/10.1787/9789264119536-en

Paz A., V., G. Gray-Molina, W. Jimenez Pozo, and E. Yañez Aguilar. 2014a. "Explaining Low Redistributive Impact in Bolivia." In The Redistributive Impact of Taxes and Social Spending in Latin America edited by Nora Lustig, Carola Pessino and John Scott. Special Issue, Public Finance Review 42, no. 3.

------2014b. CEQ Master Workbook: Bolivia. CEQ Data Center on Fiscal Redistribution (CEQ Institute, Tulane University), version: September 22.

Pechman, J. A. 1985. Who Paid the Taxes, 1966-1985. Brookings Institution, Washington, D.C.

Rossignolo, Dario. 2018. "Taxes, Expenditures, Poverty, and Income Distribution in Argentina," Chapter 11 in Commitment to Equity Handbook. Estimating the Impact of Fiscal Policy on Inequality and Poverty, edited by Nora Lustig (Brookings Institution Press and CEQ Institute, Tulane University). Advance online version available at http://www.commitmentoequity.org/publications/handbook.php. 
. 2017. CEQ Master Workbook: Argentina. CEQ Data Center on Fiscal Redistribution (CEQ Institute, Tulane University), version 19.

Sahn, D. and S. Younger. 2000. "Expenditure Incidence in Africa: Microeconomic Evidence," Fiscal Studies 21(3): 329-347.

Sauma, P. and J. D. Trejos. 2014a. "Gasto público social, impuestos, redistribución del ingreso y pobreza en Costa Rica.” CEQ Working Paper No. 18, Center for Inter-American Policy and Research and Department of Economics, Tulane University and Inter-American Dialogue.

2014b. CEQ Master Workbook: Costa Rica. CEQ Data Center on Fiscal Redistribution (CEQ Institute, Tulane University), version February 14.

Scott, J. 2014. "Redistributive Impact and Efficiency of Mexico's Fiscal System." In The Redistributive Impact of Taxes and Social Spending in Latin America edited by Nora Lustig, Carola Pessino and John Scott. Special Issue, Public Finance Review 42, no. 3.

------- 2013. CEQ Master Workbook: Mexico. CEQ Data Center on Fiscal Redistribution (CEQ Institute, Tulane University), version: September 2.

Shimeles, A., A. Moummi, N. Jouini and N. Lustig. 2016. "Fiscal Incidence and Poverty Reduction: Evidence from Tunisia." CEQ Working Paper No. 38, CEQ Institute, Tulane University. "CEQ Assessment: Tunisia." Also in 2018. Commitment to Equity Handbook. Estimating the Impact of Fiscal Policy on Inequality and Poverty, edited by Nora Lustig, (Brookings Institution Press and CEQ Institute, Tulane University). Advance online version available at http://www.commitmentoequity.org/publications/handbook.php.

2015. CEQ Master Workbook: Tunisia. CEQ Data Center on Fiscal Redistribution (CEQ Institute, Tulane University and African Development Bank), version: October 1.

Stiglitz, Joseph E. 2012. The Price of Inequality. W. W. Norton and Company, New York.

Younger, S. D., and A. Khachatryan. 2017. "Fiscal Incidence in Armenia." In The Distributional Impact of Fiscal Policy: Experience from Developing Countries, edited by Gabriela Inchauste and Nora Lustig. Washington, D.C.: World Bank.

-2014. CEQ Master Workbook: Armenia. CEQ Data Center on Fiscal Redistribution (CEQ Institute, Tulane University and the World Bank), version: May 31.

Younger, S. D., F. Myamba, and K. Mdadila. 2016a. "Fiscal Incidence in Tanzania." CEQ Working Paper No. 36, Center for Inter-American Policy and Research, Tulane University Ithaca College and REPOA. 
------ 2016b. CEQ Master Workbook: Tanzania. CEQ Data Center on Fiscal Redistribution (CEQ Institute, Tulane University), version: June 1.

Younger, S. D., E. Osei-Assibey and F. Oppong. 2015. "Fiscal Incidence in Ghana." CEQ Working Paper No. 35, Center for Inter-American Policy and Research, Tulane University, Ithaca College, University of Ghana and the World Bank.

2016. CEQ Master Workbook: Ghana. CEQ Data Center on Fiscal Redistribution (CEQ Institute, Tulane University), version: February 10. 